\title{
Hanefî-Mâturîdî Firak Geleneği Bağlamında Mezheplerin Tasnifi Meselesi
}

\author{
MUZAFFER TAN \\ DR., ANKARA Ü. İLAHIYAT FAKÜLTESI \\ e-posta: tanmuzaffer@yahoo.com
}

\begin{abstract}
The Problem of Classification of Islamic Sects in the Context of Hanafite-Maturidite Heresiography. In recent times, a certain increase has been observed in the number of studies on the methodological approach in the field of History of Islamic Sects, and in this sense, the attention has particularly been focused on the heresiographical literature as the primary sources of the field. However, given the fact that these works were composed within different heresiographical traditions, some problems may arise in analyzing the method and contents of the works properly, and identifying the interaction among them. One of these heresiographical traditions that appeared in the Islamic culture is Hanefite-Maturidite heresiography. Although recently some studies have been done on this heresiography, except for a few, they basically consist of brief considerations, in a sense, introductory notes to the matter. In this context, this article aims to identify some of basic texts belonging to the tradition in question, to analyze their distinctive literary features and to give information of their contents.
\end{abstract}

key words: Hanafite-Maturidite Heresiography, Kitâb al-Maqâlât, al-Mâturîdî, al-Nasafî, Sects, Firaq.

\section{Giriş}

İlk dönem İslâm mezhep ve fırkaları hakkında yapılmış çalışmalar, başlangıç noktası olarak temelde klasik firak gelenekleri arasında Eşarî-Mutezilî eserleri esas almışlardır. Bunların dışında araştırmacıların çalışmalarında kaynak olarak kullanabilecekleri diğer firak türü eserler son derece azdır. Erken dönemde ortaya çıan fırkaların görüşlerine doğrudan kendi kaynaklarından ulaşmak mümkün olmadığından, araştırmacılar fırkaların savundukları görüşlere daha geç dönemde yazılmış firak türü eserler kanalıyla ulaşmak 
durumundadırlar. Söz konusu klasik geleneğin kapsamında yer alan eserler arasında Eş'arî (ö. 324/935), ${ }^{1}$ Bağdâdî (ö. 429/1037), ${ }^{2}$ İbn Hazm (ö. 456/ 1064), ${ }^{3}$ Şehristânî (ö. 548/1153) ${ }^{4}$ ve Neşvânu'l-Himyerî (ö. 573/1175) ${ }^{5}$ gibi yazarların meşhur çalışmaları yer aldığından, akademik referanslarda Eş'arî, kısmen de Mu'tezilî söylem hâkimdir. Bununla birlikte bu eserler, erken döneme ait muhtelif tartışma konularını içerseler de, Müslüman âlimlerin fırkalara dair üretmiş oldukları bilgilerin tamamını zikretmezler. ${ }^{6}$

Bu bağlamda gerek içerik, gerek üslup ve gerekse tasnif bakımından söz konusu fırak gelenekleri dışında Hanefî-Mâturîdî fırak geleneği olarak isimlendirilebilecek müstakil özgün bir geleneğinin varlığından bahsetmek gerekmektedir. Bugüne kadar tam anlamıyla gün ışığına çıkarılamadığından dolayı söz konusu gelenek ilim mahfillerinde gerekli ilgiyi göremeyerek, çok az bilgi sahibi olunan bir gelenek olarak kalmıştır. Bu açıdan fırak gelenekleri içerisinde hak ettiği yeri alabilmesi için bu geleneğin önde gelen bazı eserlerinin tahlil edilerek ortaya konması önem arz etmektedir. ${ }^{7}$

Hanefî-Mâturîdî fırak geleneğine zemin teşkil edecek ilk Mürciî-Hanefî eserlerin ne zaman ortaya çıktığına dair kesin bir şey söylemek mümkün olmamakla birlikte, III/IX. asırda gerek Hanefî, gerekse diğer çevrelerde reddiye tarzında birtakım eserlerin kaleme alındığı bilinen bir husustur. $\mathrm{Bu}$ anlamda Hanefî Muhammed b. el-Yemân es-Semerkandî (ö. 268/881)'nin Kerrâmiyye'ye karşı yazdı ğı er-Red 'alâ'l-Kerrâmiyye ${ }^{8}$ ve Muhammed b. Ahmed b. Hafs el-Kebîr (ö. 270/883)'in er-Red 'alâ'l-Lafziyye ve Kitâbu'l-Ehvâ ve'l-

1 el-Eş'arî, Ebû'l-Hasan Ali b. İsmail, Makâlâtu'l-İslâmiyyîn ve İhtilâfu'l-Musallîn, thk. Muhammed Muhyiddin Abdulhamid, Beyrut 1995.

2 el-Bağdâdî, Abdulkâhir Tâhir b. Muhammed, el-Fark beyne'l-Furak, thk. Muhammed Osman Huşt, Kahire 1988.

3 İbn Hazm, Ebû Muhammed Ali b. Ahmed ez-Zâhirî, el-Fasl fǐl-Milel ve'I-Ehvâ ve'n-Nihal, thk. Muhammed İbrahim Nasr-Abdurrahman Umeyra, Beyrut trz.

4 eş-Şehristânî, Ebû'l-Feth Muhammed b. Abdilkerîm, el-Milel ve'n-Nihal, thk. Ahmed Fehmi Muhammed, Beyrut 1992.

5 Neşvânu'l-Himyerî, Ebû Saîd, Hûru'l-'Tyn, nşr. Kemal Mustafa, Kahire 1948.

6 Krş. Lewinstein, Keith, "Notes on Eastern Hanefite Heresiography", JOAS, 114, 4 (1994), s. 583.

7 Son dönemlerde Hanefî-Mâturîdî firak geleneğine dair birtakım çalıșmalar yapılmıștır. Bununla birlikte bu çalışmalar, temelde meseleyi kapsamlı bir şekilde ele almaktan çok, giriş mahiyetinde kısa çalışmalardır. Dolayısıyla bu konuda daha spesifik bilimsel çalışmalara ihtiyaç olduğu aşikârdır. Mesela bkz. Lewinstein, Keith, Studies in Islamic Heresiography: The Khawârij in Two Firaq, Princeton 1989; "Notes on Eastern Hanefite Heresiography", JOAS, 114, 4 (1994), s. 583-593; Fığlalı, Ethem Ruhi, "Burdur Kütüphanesi'nde Bulunan Bir Risale: Tezkiretü’l-Mezahib", AÜiİED, Say1: 2 (1975), s. 99-102.

8 en-Nesefî, Ebû'l-Mu'în Meymûn b. Muhammed, Tebsiratu'l-Edille fî Usûli'd-Dîn, thk. Claude Selame, Şam 1992, I/164. 
İhtilâf ${ }^{\natural 9}$ adlı eseri bu fırak geleneğinin ilk örnekleri arasında zikredilebilir. ${ }^{10}$ Ayrıca, ilerde değinileceği üzere, Hanefî fırak geleneği içerisinde yer alıp günümüze ulaşan en eski eser konumundaki Ebû Mutî‘ Mekhûl b. el-Fadl en-Nesefî'nin (ö. 318/930) Kitâbu'r-Redd 'alâ Ehli'l-Bida've'l-Ehvâ adlı eserinin içerik ve şekil açısından son derece sistematik bir yapı arz etmesi, bu gelenek içerisinde Nesefi'den daha önce yazılmış, muhtemelen III/IX. asrın ortalarına kadar geriye götürülebilecek benzer çalışmaların var olabileceğini göstermektedir. Nitekim Lewinstein'in de belirttiği gibi, bizzat Nesefî, fırkaların isimlerini, belki de fırak taslağının tamamını ${ }^{11}$, başkalarından aldığını belirterek bu hususu teyit etmektedir. ${ }^{12}$ Ayrıca, Nesefî'deki reddiye kısımlarının yapısı, bu eserin, elimizde bulunanların en eskisi olsa bile, benzerleri arasında ilk olmadığını göstermektedir. Bu kısımlarda yazar sürekli olarak "Cemaat şöyle dedi (kâleti'l-cemâ'a)" ifadesiyle başlayıp akabinde genel olarak "Ebû'l-Muti'şöyle dedi (kâle Ebû Mutî')" ibaresiyle devam eder. Dolayısıyla Nesefî'nin "Cemaatinkiler" ile "kendi" görüşleri arasında bir ayırıma gitmesi kendisinden daha eski bir fırak geleneğin varlığına dair bir işaret olarak kabul edilebilir. ${ }^{13}$ Tüm bu etkileşimleri daha net görebilmek için, Hanefî-Mâturîdî fırak geleneğinin günümüze ulaşmış eserlerini yakından incelemek ve aralarındaki benzerlik ve farklılıklara kronolojik olarak tahlil etmek gerekmektedir.

\section{Kitâbu'r-Redd 'alâ Ehli'l-Bida' ve'l-Ehvâ'}

Ebû Mutî‘ Mekhûl b. el-Fadl en-Nesefî'nin ${ }^{14}$ telif ettiği Kitâbu'r-Redd 'alâ Ehli'lBida' ve'l-Ehvâ' adlı eser, Mürcî̂-Hanefi gelenek içerisinde günümüze

9 Zehebi, Ebû Abdillah Şemsüddin Muhammed b. Ahmed b. Osman, Siyer A'lâmu'n-Nubelâ, thk. Şuayb Arnaûd-Salih es-Semr, Beyrut 1983, XII/617-618.

10 Her ne kadar Osmanlı âlimlerinden İmam Birgili (981/1573), Hanefî-Mâturîdî fırak geleneğini Ebû Hanîfe'ye dayandırmaya çalışmısssa da (Bkz. İlhan, Avni, "Birgili Mehmet Efendi ve Mezhepler Tarihi ile İlgili Risalesi (Tühfetü'l-Müsterşidîn fi Beyani Furaki'l-Mezâhibi'l-Müslimîn), DE$\ddot{U I F}$, VI (1984), s. 184, 200) bunun gerçek olma ihtimali son derece azdır. Muhtemelen Birgili'nin yapmak istediği, tarihi bir gerçeği tespitten ziyade, Aydınlı'nın da belirttiği üzere (Aydınlı, Osman, Osmanlı'dan Cumhuriyet'e İslâm Mezhepleri Tarihi Yazıcılı̆̆ı, Çorum 2008, s. 124-25) tarihin geriye doğru işletilerek söz konusu firak geleneği için Ebû Hanîfe'yi başlangıç noktası olarak alma arzusu olmalıdır.

11 Lewinstein, s. 591.

12 "Beleğanâ 'an tesmiyyetihim ennehum sittetu asnâf", Nesefî, s. 60. Ayrıca Nesefî, eserinde kullandı̆̆ı malzemenin bir kısmı için istifade ettiği şahısların isimlerini verir, s. 118.

13 Bkz. Lewinstein, s. 591.

14 Ebu Mutî’nin hayatı hakkında, kaynaklarda son derece az bilgi yer almaktadır. Kaynaklarda Hanefî bir fakih, muhaddis ve hâfız olarak nitelenen Nesefî̀ye ayrıca el-Lu'lu'iyyât ve Kitâbu's Şu'â' fíl-Fıkh adlı eserler de nispet edilir. (İsmail Paşa el-Bağdâdî, Hediyyetu'l-'Ârifinn Esmâu'lMuellifîn ve Âsâru'l-Musannifin, İstanbul 1955, II/470; Kehhâle, Ömer Riza, Mu'cemu'l-Muellifinn, Beyrut 1993, III/907 ). Zehebî, onun Ebû İsâ et-Tirmizî (ö. 279/892), Davud ez-Zahirî (ö. 270/ 883), Abdullah b. Ahmed b. Hanbel (ö. 290/903), Muhammed b. Eyyub b. ed Durays (ö. 294/ 
ulaşabilmiş önemli ve muhtemelen en eski çalışmalardan birisidir. Bu eser kaynaklarda yeterince zikredilmemiş olmakla birlikte, ${ }^{15}$ batılı önde gelen bazı araştırmacıların dikkatinden kaçmamıştır. Mesela Massignon, eserin önemine dikkat çekmekle birlikte, öncelikle Mekhûl en-Nesefînnin sûfî ve Kerrâmi bağlantıları üzerinde durmuş ve Fırak ilmi açısından taşıdığı önemi çok fazla tartışma gereği duymamıştır. Yine önde gelen Batılı araştırmacılardan Joseph van Ess bu eseri daha çok Kerramiyye ile ilişkilendirerek müstakil bir fırak geleneği bağlamında herhangi bir hususa dikkat çekmemiştir. ${ }^{16}$

Eserin metni, Marie Bernand tarafından 1980 yılında neşredilmiştir. ${ }^{17}$ Öncelikle eserde Ebû Hanîfe (ö. 150/767)'ye yapılan birçok atıftan yazarın açık Hanefî kimliği ortaya çıkmakta olup ${ }^{18}$ bu durum, onun Mürcî̂-Hanefî bir iman tarifine sıkça atıfta bulunmasıyla da doğrulanır. ${ }^{19}$ Ayrıca Nesefî’nin taklide karşı nazarı destekleyen ifadeleri, ${ }^{20}$ Mâturîdî (ö. 333/944)'nin Kitâbu't-Tevhîd'in baş tarafinda söyledikleriyle, ${ }^{21}$ gerek dil gerekse içerik açısından son derece benzeşmektedir. Daha da ötesi yazarın Mutezilî karşıtı, fakat Eşarî olmayan kelamî duruşunun sonraki Mâturîdî eserlerle örtüşmesi ${ }^{22}$ eserin Mürcî̂-Hanefi firak geleneğine aidiyetini destekleyen hususlar arasında yer alır. Ayrıca yazarın yetmiş iki fırkayı cemaatten ayrılmış sapkın ve bidat sahibi fırkalar şeklinde niteleyerek, cehennem ateşine gireceklerini belirtmesine rağmen, tevhit inançlarından dolayı, Allah'ın dilemesiyle cehennemden çıkabileceklerini ifade etmesi ${ }^{23}$ onun söz konusu mezhebi duruşunu izah eder mahiyettedir. ${ }^{24}$

Yazar eserin başında Ahmed b. Osman el-Makdisî'den rivayetle insanların Sünnet hakkında düştükleri ihtilaflardan ve her firkanın Sünnet'e daha

906), Mutayyan (ö. 297/909) gibi âlimlerden rivayette bulunduğundan bahseder, Siyeru Alâmi'n-Nubelâ, XV/33.

15 Esere Pezdevî ve Kannevcî gibi Mâturîdî âlimler tarafından işaret edilmiş olup başka kaynaklarda esere dair herhangi bir kayda rastlanmamıştır (Bkz. Ebû Yusr Muhammed, Usûlu'd-Dîn, çev. Şerafettin Gölcük, Ehl-i Sünnet Akâidi, İstanbul 1988, s. 347; al-Kannevcî, Abdu'l-Vehhâb, Bahru'l-Mezâhib, Berlin, Spr. 706, Ahlwardt 1851, vr. 193a).

1 6Bkz. Lewinstein, Studies in Islamic Heresiography, s. 158-59.

17 M. Bernand, "Le Kitâb al-Radd alâ l-Bida", Annales islamologiques 16 (1980) s. 8-126.

18 Bkz. Nesefî, s. 76, 81, 121.

19 "İman sözdür, ameller ise onun uygulamalarıdır (şerâi'uh)", s. 62, 69, 70.

20 Bkz. Nesefî, s. 54-55.

21 Maturidî, Kitâbu't-Tevhîd, thk. Fethullah Huleyf, Beyrut 1960, s. 3-4.

22 Lewinstein, Studies in Islamic Heresiography, s. 159.

23 Bkz. Nesefî, s. 59.

24 Büyük günah işleyenin durumuna dair Mürcî yaklaşım hakkında geniş bilgi için bkz. Kutlu, Sönmez, Türkelerin İslamlaşma Sürecinde Mürcie ve Tesirleri, Ankara 2000, s. 104-122; Pessagno, Meric J., "The Murji'a, Îmân and Abû 'Ubayd”, Journal of the American Oreintal Society, 95.3 (1975), s. 382-384. 
yakın olduğu yönündeki iddialarından bahseder. Bu durum, muhtemelen eserin kaleme alınmasındaki ana nedeni oluşturmaktadır. Şöyle ki Sünnetin mahiyeti ve kimin Ehl-i Sünnet olduğu meselesi üzerinde nazar etmeye karşı olanlara itiraz eden Nesefî, bidatlerden sakınabilmek için sünnetin bilinmesinin gerekliliğini bilhassa vurgular. ${ }^{25}$ Akabinde yazar, dinin savunulup korunabilmesi için bidatlerin bilinip ortaya konmasının gerekliliğinden bahseder. Burada üzerinde durulan bir diğer husus da bidat sahiplerinden uzak durulması, onlarla oturup kalkılmaması meselesidir. ${ }^{26}$ Böylece yazar, eserini yazış amacını temellendirmiş olmaktadır.

Eserin dikkat çeken özelliklerinden birisi de 73 fırka hadisinin eserin şematik inşa sürecinde belirleyici rol oynayan faktörler arasında yer almasıdır. ${ }^{27}$ Nesefî eserini, Eşarî-Mutezilî firak geleneklerinde olduğu gibi, yetmiş üç fırka hadisine göre tasnif etmekle birlikte, yetmiş üç sayısına ulaşmada onlardan farklı bir yöntem izlediği görülür. Öncelikle "Ehva Sahiplerinin Asılları'nın İsimleri (Tesmiyyetu Usûli'l-Ehvâ')" başlığını taşıyan bölümde zikredilen yetmiş üç fırkanın yetmiş iki sapık fırkası altı ana gruba (asl) ayrılır. Bu altı ana firka sırasıyla Harûriyye, Ravâfıza, Kaderiyye, Cebriyye, Cehmiyye ve Mürcie'dir. ${ }^{28} \mathrm{Bu}$ fırkaların her biri de kendi içinde on iki alt gruba taksim edilir ki, böylece yetmiş iki sapık fırka sayısına ulaşılmış olur. Burada dikkat çekilmesi gereken husus bu tasnif biçiminin $(6 \times 12)+1=73$ daha sonraki Hanefî-Mâturîdî furak geleneğinde titizlikte korunmuş olduğudur. Dolayısıyla Nesefî̀ni bu eseri, Hanefî-Mâturîdî fırak geleneğinin yapısal formunu belirleyen en erken ve en önemli eserler arasında kabul edilebilir.

Söz konusu bu altı ana grup ve alt firkaların dışındaki yetmiş üçüncü fırkaya, yani kurtuluşa eren firkaya (el-firkatu'n-nâciye) gelince, Nesefî bu fırkanın Ehlu'l-Cemâ'ati'l-Murci'ûn olduğunu belirterek, aynı zamanda kendi mezhebi kimliğini ortaya koyar. Burada yazar bir taraftan sapkın altı ana fırka arasında Mürcie'yi sayarken, ${ }^{29}$ diğer taraftan Ehlu'l-Cemâ'ati'l-Murciûn'u kurtuluşa eren fırka olarak görmesi, onun iki farklı kesimden bahsettiği şekline anlaşılabilir. Nitekim Mürcie olarak isimlendirilen kesimin çok da homojen olmadığı göz önüne alındı̆̆ında, burada yazarın Mürcie'den Mezmûm Mürcie'yeyi kastetmiş olma olasılığı son derece yüksektir. ${ }^{30}$ Ayrıca Nesefî'nin, akabinde Ehl-i Cemâ'at olarak atıfta bulunduğu bu grubun akla

25 Bkz. Nesefî, s. 54-55.

26 Bkz. Nesefî, s. 57-59.

27 Bkz. Nesefî, s. 60.

28 Bkz. Nesefî, s. 60.

29 Bkz. Nesefî, s. 67.

30 Mürcie kavramının tespiti, içeriği ve kavramın gelişim süreci hakkında geniş bilgi için bkz. Kutlu, Türklerin İslamlaşma Sürecinde Mürcie ve Tesirleri, s. 28-39. 
ve reye çok fazla önem verdiklerinden sitayişle bahsetmesi onun Ehl-i Cemaat adını verdiği Mürcie ile Ehl-i Rey'i kastettiği anlaşılmaktadır. ${ }^{31}$

Nesefî̀nin eserinde görüşlerine yer vererek eleştirdiği ilk fırka Harûriyye, yani Haricilik'tir. Burada izlenen yöntem, öncelikle ele alınan ana fırkanın temel görüşlerini özet hâlinde zikredilmesinin akabinde, cevap mahiyetinde bir reddiye bölümüne yer verilmesidir. Aslında bu yaklaşım biçimi yazarın eserin tamamında izlediği bir yoldur. Harûriyye'nin iddialarında yazarın öne çıkardığı temel husus, Hâricî zihniyetin en mümeyyiz vasfı olan iman-amel bütünlüğü meselesidir. Burada verilen bilgiler Harûriyye firkasını bidat ehlinden yapan temel referans çerçevesi olup ona yapılacak tüm itirazlar bu çerçeve üzerinden yürütülür: Onlara göre "İman, söz ve amelden ibarettir"; Ali, amellerinde kusurlu davranmış ve İman kusur (taksîr) kabul etmeyeceğinden dolayı Ali küfre girmiştir. Bu nedenle Harûriyye, Ali'yi tekfir ederek ondan teberri etmiştir.

Yazar, Hâricî yaklaşımı ana hatlarıyla ortaya koyduktan sonra, "Cemaat şöyle demiştir" ibaresiyle başlayarak kendi görüşünü dile getirir. Burada, "imanın Allah'ı ikrar etme, amellerin ise imanın uygulamaları (şerâi') olduğu" belirtilerek ${ }^{32}$ iman ve amel birbirinden ayrilır. Dolayısıyla ümmetten kimsenin Ali'nin Allah'a olan inancının tartışmayıp sadece onun amellerinde hatalı olup olmadığı konusunu tartıştıkları belirtilerek Hâricî görüşün yanlışlığı ortaya konur.

Bu bölümün sonunda İbn-i Abbas'tan rivayet ettiği bir hadisle yazar, adeta bütün fırkalar karşısında kendi mezhebî duruşunu beyan eder: "Bilmediğin şeyi geriye bırak (ircâ'), fakat Mürciî olma; Ehl-i Beyt'i sev, fakat Şiî olma; de ki Allah adaletli olmayı, iyi şeyler yapmayı ve yakınlara yardımda bulunmayı emreder, fakat Kaderî olma; iyiliği emredip kötülükten sakındır, fakat Harûrî olma". ${ }^{33}$ Böylece yazar, muhtemelen mezmûm mürcie anlamında ne Mürciî, ne Şiî, ne Mutezilî, ne de Hâricî olduğunu ima etmektedir.

Râfızayla ilgili olarak yazarın zikrettiği hususların başında Râfıza kavramına dair söyledikleri gelmektedir. Ona göre bu grup, Ali'yi aşırı severek, âsâr ve sünneti terk (rafz) etmelerinden dolayı Râflza olarak isimlendirilmiştir ${ }^{34}$ ki bu, Râfıza tabirinin kökenine dair tartışmalar noktasında ilginç bir yaklaşım olup bu hususta diğer kaynaklarda söylenenlerden farklı bir içerik taşır. Ravâfıza'nın temel iddiasına gelince,

31 Bu hususta geniş bilgi için bkz. Kutlu, Sönmez, "Ebû Mansûr el-Mâturîdî’nin Mezhebî Arka Planı”, İmam Mâturîdî ve Maturidilik, Haz. Sönmez Kutlu, Ankara 2003 içinde, s. 120 vd.

32 "el-İmân ikrârun bi'llâh ve'l-amel bi-şerâ’ih" Bu ifade önce cemaatin görüşü olara zikredildikten sonra bunun aynı zamanda Hz. Peygamberden rivayet edilen bir hadis olduğu belirtilir, s. 62 .

33 Bkz. Nesefî, s. 63.

34 Bkz. Nesefî, s. 63. 
yazar bunu onların Hz. Ali'yi sevmede aşırı gitmeleri ve onu Hz. Peygamber, Muhacirîn ve Ensar'ın üzerinde bir konuma yerleştirmeleri şeklinde formüle eder. ${ }^{35}$ Burada önemli olan Râfıza'nın, yani Şia'nın temel görüşlerinin ele alınmasından öte, yazarın kendi mezhebî duruşuna karşıt bir çerçeve, bir "muhalif" oluşturarak, bu görüşlerin reddedilmesi için gerekli teorik zeminin oluşturulmak istenmesidir.

Râfıza'dan sonra Kaderiyye firkasının temel görüşünden bahsedilir. Yazara göre bu firkanın temel görüşü, Allah'ın dilemesini (meşiet), yaratmasını (tahlîk), kaza ve kaderini inkâr etmeleridir. Onlara göre hayır Allah'tan, şerr ise inananların kendisinden veya Şeytan'dan gelmektedir. ${ }^{36}$ Bir diğer firka olan Cebriyye'nin temel iddiasına gelince, yazara göre bu firka, birtakım çirkin şeyleri Allah'a nispet ederek insanların günah işlemediklerini öne sürmüştür. Bu noktada insanın, fiilden önce veya sonra olsun, yapabilme gücünü (istitâ'a) her halükarda reddederek onu sadece Allah'a ait kılmıştır. Yazar, bu görüşü reddederek Cemaat'in görüşünü zikreder. Buna göre fiiller kullara ait olup, kaza, kader ve yaratma Allah'a aittir. ${ }^{37}$

Beşinci olarak ele alınan Cehmiyye fırkasının öne çıkarılan görüşü, Allah'ın her türlü benzetmenin dişında tutularak, onu her türlü nitelemenin, adlandırmanın, mananın ve ispatın ötesinde görülmesidir. Onlara göre Allah'a şey demek doğru değildir. Yazar'ın bu ifadelerden sonra Cemaat'e nispet ederek zikrettiği sahih yaklaşım ise, Allah'ın şey olmakla birlikte, diğer şeyler gibi olmadığı şeklindedir. O, şeylerin (eşyâ) yaratıcısı olup bütün sıfat ve fiilleriyle ezelidir. ${ }^{38}$

Altıncı ve son fırka olan Mürcie'ye gelince, bu fırkanın en bariz görüşü, onun amel olmaksızın sadece imana dayanarak, imanın var olması halinde kötü amelin (seyyie) imana zarar vermeyeceğini öne sürmesidir. Yazar, bu görüşü birtakım ayet ve hadisleri zikrederek reddeder. ${ }^{39}$

Bu altı ana fırkanın görüşlerinin herhangi bir şahsa nispet edilmeksizin anonim olarak verilmesi dikkat çekici bir husustur. Yazar şahıslardan çok, soyut fikirleri zikrederek bu fikirlerin reddedilmesi ile uğraşmaktadır. Dolayısıyla onun için bunların kime ait olduklarının pek önem arz etmediği an-

35 Bkz. Nesefî, s. 63. Yazar burada Ravâfıza'nın Harûriyye gibi “imanın amelin dışında bir söz olduğunu" söylediğini belirtir ki bu ifadesi daha önce Harûriyye'nin iman tanımına dair söyledikleriyle çelişmektedir (s. 62). Ayrıca bu cümlenin hemen akabinde gelen "Ali'nin masum olduğu, dolayısıyla ona hiçbir günah nispet edilemeyeceğini iddia ettikleri" ifadesi de bir önceki cümlesine uygun düşmemektedir. Dolayısıyla bu cümlede bir ibare düşmesi veya yazımdan kaynaklanan bir hata olmalıdır.

36 Bkz. Nesefí, s. 64.

37 Bkz. Nesefî, s. 65.

38 Bkz. Nesefí, s. 66-67.

39 Bkz. Nesefî, s. 67-68. 
laşılmaktadır. Çünkü her bir fırkaya nispet edilen bu görüşler, okuyucunun/ mezheptaşlarının gerçek anlamda bilgilenmesi amacından çok, mümkün olduğunca yalın bir formda ve reddiyeci bir yaklaşımla ele alınır. Nitekim yazarın bu fırkaları birtakım rivayetlerle Hz. Peygamberin ağzından lanetlemesi onun gerçek amacını izah eder mahiyettedir. Mesela, bu fırkalar eserin bir yerinde Harûriyye ve Kaderiyye ${ }^{40}$ bir başka yerinde Kaderiyye, Harûriyye ve Râfıza ${ }^{41}$ ve son olarak da Mürcie-Kaderiyye şeklinde ${ }^{42}$ lanetlenirler.

Eserde dikkat çeken bir diğer özelliği de fırka isimlerinin standart fırak geleneğinden farklı bir formda verilmesidir. Yazar, yaygın olarak bilinen formlarını dikkate almaksızın hemen her firkanın sonuna "-iyye" nispet ekini getirerek fırkaların isimlerini farklı bir formda takdim eder. Mesela daha çok Ezârika olarak bilinen Hâricî fırkası Ezârikiyye şeklinde isimlendirilirken, bir diğer Hâricî fırkası Muhakkime keza Muhakkimiyye şeklinde verilir. Bu durum diğer fırkalar için de geçerlidir.

Altı ana firkanın temel görüşlerinden sonra her bir ana firkanın alt gruplarından ayrıntılı bir şekilde bahsedilir. Burada karşımıza çıkan durum, eserde fırkalara nispet edilen görüşlerin Eşarî-Mutezilî fırak eserlerinden son derece farklı olmasıdır. Öyle ki daha önce fikirleri hakkında bilgi sahibi olduğumuz çok sayıdaki fırkaya burada çok daha farklı görüşler nispet edilmektedir. Bu durumun ilerde görüleceği üzere aslında tüm HanefîMâturîdî firak eserleri için söz konusu olduğu söylenebilir.

Bu bölümde ilk olarak Harûriyye'nin on iki alt kolu ele alınır. Yazarın burada izlediği yöntem önce her fırkanın görüşlerinin dile getirdikten sonra Cemaat'in bu iddialara verdiği cevapları vermekten ibarettir. Aslında bu yöntem, daha önce zikredilen altı ana fırka dâhil, eserin tamamı boyunca izlenmiştir. Yazarın böyle bir yaklaşımı benimsemiş olması, daha önce belirtildiği üzere, muhtemelen fırkaların görüşlerini zikretmekten çok, onların söz konusu fikirlerinin reddine yönelik uygun bir çerçeve oluşturmak çabasindan kaynaklanmaktadır.

Fırkaların isimlendirilmesinde yazarın iki farklı yaklaşım içinde olduğu söylenebilir. Bunlardan birincisi, Kûziyye, Kenziyye, Muhakkimiyye ve Muteziliyye gibi fırka isimlerinde olduğu gibi fırkaların savundukları fikrin

40 Ümmetimden iki sınıf vardır ki, onların şefaatimden bir nasipleri olmayacaktır. Bunlar Harûriyye ve Kaderiyye'dir. s. 63.

41 Kaderiyye'nin sözleri küfür, Harûriyye'ninkiler helak edici, Rafıza'nınkiler ise dalâlettir.”, s. 3. Bir diğer yerde ise şu rivayet geçer: "Ahir zamanda Ehl-i Beytimi sevmede aşın gidecek bir topluluk çıkacaktır. Onlardan uzak durun; onlar Ravâfıza'dır...", s. 64.

42 "Ümmetimden iki sınıf vardır ki onlara şefaatim ulaşmayacaktır. Bunlar Mürcie ve Kaderiyye'dir." s. 68. 
aslını teşkil edebilecek belli bir kavram, ibare ya da temel görüşe göre isimlendirilmeleridir. İsimlendirmede izlenen diğer bir yol fırkanın lideri konumundaki kişiye nispet edilmesidir. Ezrakiyye, İbâdiyye, Hâzımiyye, Halfiyye, Şemrâhiyye, Ahnesiyye ve Meymûniyye bu hususa örnek teşkil eden fırkalardandır. Ayrıca Harûriyye üst başlığı altında zikredilen bu alt fırkaların birbiriyle fiilen bağlantılı olduklarına dair somut bir kanıt da yoktur. Hiç bir grup bir diğerinin görüşlerine, iddialarına karşı herhangi bir reaksiyon göstermez ve bu fırkaların hangi zaman dilimlerinde ortaya çıktıklarına dair herhangi bir ipucu da verilmez. Dolayısıyla firkalar tarihsel, kültürel ve sosyal bağlamlarından tamamen tecrit edilerek verilmişlerdir.

Öte yandan hiçbir fırkanın ismine dair herhangi bir izahat ya da şahısla ilişkilendirilmeleri söz konusu edilmez. Bununla birlikte fırkaların bağlamında tamamen koparılarak verilmesi, ya da şahıslardan doğrudan bahsedilmemesi, yazarın onlar hakkında herhangi bir bilgi sahibi olmamasından çok, muhtemelen bu bağlamların ve isimlerin zikredilmesinin eserin yazılış amacı için fazla bir önem arz etmemesinden kaynaklanmaktadır.

Altı ana gruba ait alt fırkaların her biri hemen hemen aynı şekilde ele alınır: Bir ya da iki temel görüş çok kısa bir biçimde verildikten sonra çoğunlukla Kuran'dan birkaç ayet ve hadisten oluşan reddiye faslı takip eder. Bu yaklaşım Mürcî̂-Hanefî fırak geleneğinin bariz niteliklerinden birisidir. Lewinstein'in de belirttiği gibi aklî/mantıkî deliller yerine büyük oranda nakli delillere dayanmanın Eşarî fırak geleneğinden çok Mürciî-Hanefî geleneğe ait bir durum olduğunu söylemek ${ }^{43}$ yanlış olmaz. ${ }^{44}$

43 Lewinstein, Studies, s. 166.

44 İlk olarak Haruriyye'nin on bir alt kolu sırasıyla ele alınır. Bunlar Ezrakiyye, İbadiyye, Tağlebiyye (muhtemelen Sa'lebiyye), Hâzımiyye, Halfiyye, Kûziyye, Kesriyye, Şemrâhiyye, Ahnesiyye, Muhakkimiyye, Muteziliyye ve Meymûniyye'ir. İkinci olarak Ravâfıza'nın alt firkaları ele alınmaktadır. Bu firkalar sırasıyla Gulviyye, Emriyye, Şîiyye, İshâkiyye, Nâvusiyye, İmâmiyye, Zeydiyye, Abbasiyye, Mütenâsiyye, Reciyye, Lâiniyye ve Müterabbısa'dır (Bkz, s. 78-87). Her ne kadar eserin baş tarafında Râfıza'nın alt kollarının isimleri zikredilirken ilk sırada Gulviyye geçmekteyse de (s. 61) dah sonraki sayfalarda alt fırkaların görüşleri verilirken, Gulviyye yerine Aleviyye ifadesine yer verilmişse de, bunun bir istinsah hatasından kaynaklandı̆̆ı ve nâşirin de bu hatayı tashih etmeksizin olduğu gibi verdiği anlaşılmaktadır, s. 78).

Üçüncü olarak, Kaderiyye'nin alt firkaları ele alınır. Bunlar Ahmediyye, Seneviyye, Mutezile, Keysâniyye, Şeytâniyye, Şerîkiyye, Vehmiyye, Zevendiyye (muhtemelen Ravendiyye), Müteberrie, Nâkise, Kâsıtiyye ve Nazzâmiyye'dir (s. 87-96). Burada dikkat çekici hususlardan birisi Keysâniyye fırkasının Kaderiyye içerisinde bir fırka olarak mütalaa edilmesidir.

Dördüncü olarak Cebriyye fırkasının alt fırkaları zikredilir. Bu fırkalar Muztarriyye, Enfâliyye, Maiyye, Mefrûğiyye, Neccâriyye, Mennâniyye, Kesbiyye, Sâbıkiyye, Hubbiyye, Havfiyye, Bekriyye ve Hasbiyye'dir, s. 96-104.

Beşinci olarak Cehmiyye fırkasının alt kollarından bahsediliyor. Bunlar, Muattıla, Merîsiyye, Mültezikiyye, Vâridiyye, Ziyade ( muhtemelen Zenâdıka), Harkiyye, Mahlûkiyye, Fâniyye, Gayriyye, Vâkıfiyye, Kabriyye ve Lafziyye'dir, s. 104-114. 


\section{Risâle Fî Beyâni Gurûhi Ehli'd-Dalâle ve Makâlâtihim}

Kaynaklarda Mâturî̀î̀ye Kitâbu'l-Makâlât adında bir fırak eseri nispet edilmekteyse de, ${ }^{45}$ onun böyle bir eser yazıp yazmadığı yeterince açık değildir. Bilindiği kadarıyla böyle bir esere en erken atıf, Mâturîdî kelamcı Pezdevî (493/1099) tarafından yapılmıştır. ${ }^{46}$ Bununla birlikte, bu eserin Pezdevi tarafından bizzat görüldüğü hususunun şüpheli olduğu söylenebilir. ${ }^{47}$ Şöyle ki Pezdevî İslam fırkalarına yazılan eserlerden bahsederken, Mâturîdînnin bu hususta bir eser yazdı̆̆ını belirtir; ancak Mâturîdî ve Eşarî fırak geleneklerinin farklılıklarını göstermek amacıyla karşılaştırma yaparken, Mâturîdînnin Kitâbu'l-Makâlât'1 yerine Ebû'l-Mûti‘ Mekhûl en-Nesefî'nin Kitabu'r-Redd alâ'l-Bida' eserine başvurması ${ }^{48}$ onun Matûridî'nin eserini gördüğünü şüpheli kılmaktadır. Bununla birlikte bir diğer Mâturîdî kelamcı Ebû'l-Mu'în en-Nesefî (ö. 508/1115)'nin Maturidî’nin eserleri arasında Kitâbu'l-Makâlât'ı zikrederek ${ }^{49}$ ondan üç yerde alıntı yapmas ${ }^{50}$ Matûridî'nin böyle bir eseri olduğunu göstermektedir. Ne var ki kaynaklarda esere dair fazla bilgi olmayışı ve kendisinden son derece az iktibas yapılması, onun dar bir çevrede bilindiği şekline yorumlanabilir.

Zayıf olmakla birlikte diğer bir ihtimal de Lewinstein'e ait olup daha sonraki Mâturîdî âlimlerin, imamları Mâturîdî̀ye böyle bir eser nispet etme çabasına girmiş olabilecekleridir. Lewinstein'e göre Maturidî’nin, çă̆daşı, Kitâbu'l-Makâlâti'l-İslâmiyyîn ve İhtilâfi'l-Musallîn yazarı ve daha çok tanınan Eşarî (ö. 324/936)'nin gerisinde kalmaması yönündeki endişeler onları buna sevk etmiş olabilir. ${ }^{51}$ Bununla birlikte yukarıda bahsedildiği üzere Nesefînnin Kitâbu'l-Makâlât'tan yaptığı iktibaslar dikkate alındığında, bu ihtimalin geçersiz olduğu rahatlıkla söylenebilir. Aksi takdirde Nesefî'nin Mâturîdî'den yaptığı alıntıların hiçbir anlamı kalmamaktadır.

Yukarıda ifade edilenler bağlamında, Kahire Üniversitesi Yazmalar Bölümünde 19495 numarada kayıtlı olan on varaklık kısa bir risaleden bahset-

Altıncı ve son olarak Mürcie fırkasının alt kollan zikredilir. Bunlar Târikiyye, Sâyibiyye, Râciyye, Şâkiyye, Beyhesiyye, Ameliyye, Menkûsiyye, Müstesniyye, Müşebbihiyye, Haşviyye, Eseriyye ve Bidiyye'dir, s. 114-122.

45 Hacı Halife Katip Çelebi, Keşfu'z-Zunûn, İstanbul 1941, s. 1782; İbn Ebî̀l-Vefâ, Cevâhiru'l-Mudie fî Tabakâti'l-Hanefiyye, Haydarabad 1332, II/130; Ebû Uzbe, er-Ravdatu'l-Behiyye fî mâ beyne'lEşấira ve'l-Mâturîdiyye, Haydarabad 1924, s.4.

46 Pezdevî, Ebû Yusr Muhammed, Usûlu'd-Dîn, çev. Şerafettin Gölcük, Ehl-i Sünnet Akâidi, İstanbul 1988, s. 347.

47 Krş. Lewinstein, "Notes on Eastern Hanafite Heresiography”, s. 585.

48 Pezdevî, Ehl-i Sünnet Akâidi, s. 347.

49 Ebû'l-Mu'în Meymûn b. Muhammed en-Nesefî, Tabsiratu'l-Edille fî Usûli'd-Dîn, thk. Hüseyin Atay-Şaban Ali Düzgün, Ankara 1993-2003, I/210, 472.

50 Ebû'l-Mu'în en-Nesefî, Tabsira, I/211, 532, II/443.

51 Krş. Lewinstein, “Notes...”, s. 585. 
mek gerekir. Risalenin hemen başında doğrudan Mâturîdî̀ye atıfta bulunulmas1 $^{52}$ ve firkların tasnifi açısından Nesefî̀ye son derece benzemesi, onun Mâturidîye nispet edilen Kitâbu'l-Makâlat olabileceği ihtimalini akla getirmektedir. Bununla birlikte, daha yakından incelendiğinde, böyle bir ihtimalin söz konusu edilemeyeceği anlaşılmaktadır. Daha önce belirtildiği üzere Ebû'l-Mu'în Meymûn en-Nesefî'nin, Mâturîdî'nin Kitâbu'l-Makâlât adlı eserinden gerek imametle ilgili, ${ }^{53}$ gerekse Allah'ın ne olduğu (mâiyetullâh) meselesinde yaptığı alıntılar ${ }^{54}$ bu risalede kesinlikle mevzu bahis edilmemektedir. Ayrıca Pezdevi'de geçen rivayetlerden Kitâbu'l-Makâlât'ın daha hacimli bir eser olduğu izlenimi uyanmaktadır. Kaldı ki elimizdeki bu eser toplam 10 varaklık bir risâle olup Kitâbu'l-Makâlât ismini de taşımamakta olup eserin firkalar ile ilgili bölümü "Fî Beyâni Gurûhi Ehli'd-Dalâle ve Makâlâtihim" başlı̆̆ını taşımaktadır. ${ }^{55}$ Bu açıdan bu eserin Mâturîlîye nispet edilen Kitâbu'l-Makâlât adlı eseri olmadığı anlaşılmaktadır.

Kısaca $B G$ olarak isimlendireceğimiz bu eserin Mâturîdî̀ye nispet edilmesi ve Ebû Hanîfe'den övgüyle bahsedilerek, diğer mezhep imamları Şafiî, Mâlik ve Ahmed b. Hanbel'in üzerine çıkarılmasi ${ }^{56}$ eserin Hanefî-Mâturîdî bir çevreye ait olduğu hususunda şüpheye mahal bırakmaz. Bilhassa Ebû Hanefî̀nin diğer mezhep imamları karşısındaki faziletine yapılan vurgu, yazarın Hanefî kimliğini açık bir şekilde ortaya koyar. Ona göre Numan b. Sabit dinin siracıdır. Şafiî, Mâlik ve İbn Hanbel de böyle olmakla birlikte, son üçünün mertebesi Numan b. Sabit'ten daha aşağıdadır. Bu hususu delillendirmek için yazar Hz. Peygamberden rivayet edildiği öne sürülen bir hadise başvurur. ${ }^{57}$

Diğer yandan risalenin başlığında dikkati çeken gürûh ifadesi Farsça bir kelime olup, en azından, yazarın Arap olmadığını göstermesi açısından önemlidir. ${ }^{58}$ Ayrıca risalenin istinsah tarihinin $1134 / 1721$ y1l ${ }^{59}$ gibi son derece

52 "kâle sâhibu 'akâid Ebû Mansûr el-Mâturîdî", vr. 1a.

53 Söz konusu iktibas birkaç cümleden ibaret olup olup "mefdûlun imameti bölümünde ( $f a s l$ fi imâmeti'l-mefdûl)" zikredilmektedir: "Onun, zamanındaki insanların en faziletlisi olması, bize göre şart değildir. Bu hususta üstat (eş-Şeyh) Ebû Mansûr Kitâbu'l-Makâlat'ta şöyle demektedir: ‘̇̀mamet için gerekli şartları haiz faziletli (fâdıl) bir kimseyle imamet hususunda akid yapılmışsa, ('ukide lehu'l-imâmame), ondan daha faziletli bir kimse olsa dahi imameti geçerlidir (in'akade imâmetuh).", Tabsiratu'l-Edille, II/443.

54 Ebû'l-Mu'în en-Nesefî, Tabsira, I/532.

$55 B G$, vr. 3a.

$56 B G$, vr. 10a.

57 "Peygamber, künyesi Ebû Hanîfe, ismi Nu'man b. Sâbit olan bir şahsın kendisinden sonra geleceğini ve onun ümmetinin ışığı (sirâc) olacağını haber vermiştir.", $B G$, vr. 10a.

$58 B G$, vr. 3a.

$59 B G$, vr. 9b-11a. 
geç bir döneme ait olması da onun Mâturîdî̀ye aidiyetini şüpheli kılan bir diğer husus olarak kabul edilebilir.

Yazarın eserde firkaları ele alıș tarzı Nesefi'ye oldukça benzemektedir. Önce Ehl-i Bid'at aynı şekilde altı ana sınıfa ayrılır. Ancak bunların sıralaması Nesefî'den farklıdır. Nesefî'de sıralama Harûriyye, Ravâfıza, Kaderiyye, Cebriyyye, Cehmiyye ve Mürcie iken, burada Kaderiyye, Cebriyyye, Râfiziyye, Harûriyye, ${ }^{60}$ Cehmiyye ve Mürciyye şeklindedir. Ayrıca dikkat çeken bir farklılık da yazarın Ravâfıza yerine Râfıziyye ifadesini kullanmasıdır. Nesefî gibi fırka isimlerinin sonlarına-iyye nispet ekinin getirilmesi burada da göze çarpmaktadır. ${ }^{61} \mathrm{Bu}$ zikredilen altı ana mezhebin daha sonra sırasıyla açıklanmasına geçilir. Bu aşamada öncelikle her ana mezhebin mümeyyiz vasfı zikredildikten sonra, Ehl-i Sünnet ve'l-Cemaat'in o husustaki görüşü verilir. Daha sonra her bir mezhep on bir alt fırkaya bölünür. Böylece altı ana mezhep, on bir alt grup ve Ehl-i Sünnet ve'l-Cemmaat ile birlikte yetmiş üç fırka sayısı elde edilmeye çalışıldığı anlaşılmaktadır. ${ }^{62}$ Dolayısıyla burada Nesefí'deki $(6 \times 12)+1=73$ tasnifi yerine $[(6 \times 11)+6]+1=73$ şeklinde bir tasnifin benimsendiği söylenebilir."

Eser şekil ve içerik açısından Nesefî ile büyük benzerlikler taşımaktadır. Öyle ki Nesefînnin adeta özetlenmiş hâlidir. Fırkalar hakkında verilen bilgiler Nesefi’ye göre çok daha kısadır. Çoğu zaman Nesefînin her fırkaya dair verdiği ilk cümlesinin doğrudan iktibas edildiği izlenimi uyanır. Bazen bu ilk cümle sanki tamamlanmadan yarıda kesilmiş gibidir. ${ }^{63}$ Fırkalara karşı Ehl-i Sünnet'in cevaplarına gelince, çoğu zaman fırkaların görüşlerinin batıl olduğu ibaresiyle geçiştirilmesinin yanında nadiren kısa bir ibareyle cevap verilir. ${ }^{64}$

Ele alınan ilk ana grup Kaderiyye mezhebidir. Bu mezhebin en önemli vasfı, onların Allah'ın meşiyyet ve kazasını inkâr etmeleridir. Onlara göre adaletin şartı Allah'ın kullarını, yaptıkları işlerin maliki yapmasıdır. ${ }^{65} \mathrm{Bu}$ mezhep on bir alt gruba (sınıf) ayrilır. Bunlar sırasıyla Ahmediyye veya Şem-

60 Metinde Cerrûriyye şeklinde geçmektedir, bkz. BG, vr. 3a.

$61 B G$, vr. 3a.

$62 B G$, vr. 3a.

63 Mesela Şeytâniyye'nin iddiası zikredilirken, sadece “Onlar: 'Şeytan yaratılmamıştır.' demektedirler." cümlesi zikredilmiștir (vr. 3b) ki, bu ifade Nesefî'deki ilk cümlenin tekrarıdır. Nesefî devaminda başka şeyler de söylemektedir (s. 90 ); ancak yazar sadece bu ilk cümleyi zikretmekle yetinmektedir.

64 "Hâzâ'l-kavlun bâtılun 'inde'l-cema'â". Ahmediyye, Muteziliyye, Şeytâniye ve Nâkısiyye'nin görüşlerine cevap olarak sadece bu cümleyle yetinilmektedir.

65 El yazmasında birtakım imla farklılıkları/yanlışları vardır. Mesela adi kelimesi yerine kavi yazılmiştır. Aslında bu ifadeler Nesefî'de Ahmediyye firkasına nispet edilen ifadelerdir, BG, vr. 3a; ayrıca bkz. Nesefî, s. 64. 
riyye ${ }^{66}$ Muteziliyye, ${ }^{67} \mathrm{Ke}(\mathrm{y})$ sâniyye, Şeytâniyye, Şerîkiyye, Vehiyye, Ravendiyye, Müterebbiyye, ${ }^{68}$ Nâkısiyye, Kâsitiyye ve Nazzâmiyye'dir.

İkinci olarak, Cebriyye veya Muztarriyye'den bahsedilir. ${ }^{69} \mathrm{Bu}$ mezhebin temel görüşü, kulun emredilen veya yasaklanan hiçbir şeyi Allah'ın izni olmadan işlemeye kudretinin olmadığıdır. Bu ifade, Nesefînnin bu mezhebin ilk fırkası olan Muztarriyye için söylediklerine büyük oranda benzemektedir. Bunun yanında Muztarriyye'nin Nesefî'deki gibi bir alt fırka olarak değil de Cebriyye'nin diğer bir ismi olarak zikredilmesi, Nesefî'de Muztarriyye için söylenen şeylerin burada genel olarak Cebriyye için söylenmiş olmasını izah etmektedir. Bu mezhep sırasıyla şu on bir alt firkadan oluşmaktadır: Efâliyye, Maiyye Mefrûğiyye, Neccâriyye, Mennâniyye, ${ }^{70}$ Kesbiyye, Sâbıkiyye, Habîbiyye, Havfıyye, Bekriyye ve Hasbiyye. Burada ilk bakışta Nesefî’de Enfâliyye ismiyle geçen firkanın istinsah hatası sonucu Efâliyye şeklinde kayda geçtiği izlenimi oluşmaktaysa da, ${ }^{71}$ Nesefi’'de bu firkaya nispet edilen görüşler dikkate alındığında, farklı bir fırkanın kastedildiği anlaşılmaktadır. Şöyle ki Enfâliyye, bütün fiillerin insanlara; ancak yapabilme gücünün (istitâat) Allah'a ait olduğunu savunan bir firka şeklinde zikredilirken; Efâliyye, istitaatın, Allah'a gerek olmaksızın, fiilden önce var olduğu görüşünü savunan bir fırka olarak ortaya çıkmaktadır. Dolayısıyla burada tek bir fırkadan çok, iki farklı fırkadan bahsedildiğini söylemek daha mantıklıdır. Çünkü bu iki görüş birbirine tamamen zıt iki farklı bakış açısını yansıtmaktadır.

BG'de Maiyye fırkasının Efâliyye gibi istitaatın fiilden önceliğini iddia ettiği söylenirken, Nesefî'de istitaat ile fiil'in birlikte olduğunu iddia ettiğ i öne sürülür. Burada zikredilmesi gereken dikkat çekici bir husus vardır. BG'de Ehl-i Sünnet'in Efaliyye'ye cevabı olarak İstitaatın fiille birlikte olduğu, yani Nesefî'deki Maiyye'nin görüşü verilirken, Nesefî'de Maiyye'nin öne sürdüğü istitaat-fiil birlikteliği reddedilir ve cevap olarak istitaatın fiilden önce olduğu, yani Efaliyye'nin görüşü öne sürülür. ${ }^{72} \mathrm{Bu}$ durumda görüşlerin birbirinden sağlıklı bir şekilde tefrik edilmesi zorlaşmaktadır

Cebriyye'nin alt firkalarına dair zikredilmesi gereken bir diğer husus BG'de Mâniyye olarak geçen fırka'nın Nesefî’de Mennâniyye şeklinde geçen fırkadan çok Neccâriyye fırkası ile aynı görüşlere sahip olduğudur. Şöyle ki, BG-

66 Nesefî̀de Kaderiyy'enin genel görüşü olarak zikredilen ifadelerle, Seneviyye'ye ait görüşler burada Ahmediyye'nin görüşleri olarak verilmiştir, $B G$, vr.3a.

67 Burada Muğazziliyye olarak zikredilen fırka Nesefì'de Muteziliyye olarak verilen fırkanın kendisidir. Doğrusu Muteziliyye olmalıdır.

68 Nesefî'de Muteberde olarak zikredilir, bkz. Nesefî, s. 93.

69 Nesefi'de Muztarriyye, Cebriyye'nin bir alt kolu olarak zikredilir, bkz. Nesefî, s. 96.

70 Metinde Menâniyye olarak geçer, vr. 4b.

71 Bkz. Nesefî, s. 96; $B G$, vr. 4a-4b.

72 Bkz. BG, vr. 4a-4b; Nesefî,s. 96-97. 
'de Mâniyye Allah'ın kullarını, kulların fiilerine göre değil, kendisinin fiilleri üzerine cezalandıracağı belirtilirken, Nesefî'de çok daha farklı bir görüş zikredilmektedir. Nesefî̀ye göre Mennâniyye fırkası insanın kalbinin iyi gördüğünü iyi, kötü gördüğünü de kötü görmesi gerektiğini savunan bir fırkadır. ${ }^{73}$ Bu durumda ya BG yazarı bu fırkanın görüşleri hakkında bir şey bilmemekte ve bu sebepten ötürü böyle bir yola başvurmaktadır ya da burada iki müstakil fırka söz konusudur.

Üçüncü olarak Râfıziyye veya Gulviyye ${ }^{74}$ zikredilmektedir. Burada söz konusu fırkanın temel görüşü, onların hiçbir günahtan sakınmayıp Cebrail'in risaleti Ali'ye getirecek yerde yanlışlıkla Hz. Muhammed'e getirdiğini iddia etmeleridir. Bu mezhebin on bir alt fırkası şunlardan oluşmaktadır: Amiriyye, Şîiyye, ${ }^{75}$ İshâkiyye, Fârisiyye ${ }^{76}$, İmâmiyye, Zeydiyye, Abbâsiyye, Mütenâsihiyye, Receiyye ve Müterabbisiyye..

Dördüncü olarak Harûriyye veya Ezrakiyye'den ${ }^{77}$ bahsedilmektedir. Bu mezheb, Ali'den teberri ederek onu tekfir etmiştir. Bu mezhebin on bir alt fırkası sırasıyla şunlardan oluşmaktadır. İbâdiyye, Salebiyye, ${ }^{78}$ Hâzimiyye, ${ }^{79}$ Halefiyye, Kenziyye, ${ }^{80}$ Kûziyye, Şemrâhiyye, Ahnesiyye, Hakemiyye (Hukmiyye), Mutezile ve Hilmûniyye. ${ }^{81}$

73 Bkz. $B G$, vr. 4b; Nesefî, s. 100.

74 Her ne kadar metinde Gulaviyye şeklinde yazılmışsa da doğrusu Gulviyye'dirr. Yazar daha önce de yaptığı gibi, Gulviyye'nin fikirlerini Râfıziyye'nin temel görüşü olarak zikretmektedir. Aslında bu, yazarın bütün eser boyunca izlediği bir metottur. Muhtemelen yazarın ana fırkanın diğer ismi olarak zikrettiği isim, aslında mezhebin bir alt firkasına aittir. Bundan dolayı da bu alt fırkanın görüşü yanlışlıkla bütün mezhebe teşmil edilmiş görünmektedir (Bkz. vr. 5a). Nitekim Nesefî'de Aleviyye (Gulviyye olması gerekir) hakkında zikredilen görüşler (s. 79), yazarın Râfıziyye veya Gulviyye için zikrettiklerinin aynısıdır.

75 Metinde bu firka mensuplarının sahabenin Ali'nin yerine Ebû Bekr'i halife seçmesini günah (ehta-e) kabul ettikleri zikredilirken (vr. 5b), Nesefî’de "küfre girdikleri" tabiri kullanılmaktadır (Bkz. s. 80).

76 Nesefíde Nâvusiyye olarak zikredilen fırka ile Fârisiyye aynı fırka olmalıdır. Çünkü metinde yazarın Fârisiyye'nin görüşü olarak zikrettikleri Navusiyye'ye ait ilk cümleye çok benzemektedir. İki ayrı metindeki bu cümle şöyledir: "İ̀ne Aliyyen efdalu hâzihi'l-umme” (Nesefî, s. 81); "İnne Aliyyen efdalu'l-umme ba'de'n-nebiyy.”, $B G$, vr. $5 \mathrm{~b}$.

77 Burada Harûriyye yerine Cerrûriyye ifadesinin kullanılması imla hatasında kaynaklanmış olmalıdır. Bunun yanında daha önce karşılaşı̆̆̆ımız gibi, Ezrakiyye fırkası, Harûriyye'nin bir alt kolu olarak değil, Harûriyye'nin bir diğer ismi olarak zikredilmektedir. Bu muhtemelen yazarın yetmiş fırka üç tasnifinde esas aldığı şemaya ters düşmemek için başvurduğu bir yoldur, bkz, vr. 6 a.

78 Metinde Tağlubiyye şeklinde verilir, bkz. vr. 6a.

79 Metinde Câzimiyye olarak geçer, bkz, vr. 6a.

80 Nesefî'de benzer görüşlere sahip Kesriyye firkası zikredilmiştir. Metnin anlamından yola çıkılırsa, $B G$ 'deki ibarenin daha doğru olması muhtemeldir. Böylece Nesefî'deki “...lâkin yeksuruhu fìl-ard ilâ en yazharu'l-hakk" cümlesindeki "yuksiruhu" ibaresinin "yeknuzuhu" şeklinde okunması ve mananın da buna göre verilmesi daha uygun düșmektedir. Böylece anlam "Ancak kiși hakikat ortaya çıkıncaya kadar onu yeryüzünde çoğaltır." değil, "Ancak kişi hakikat ortaya çıkıncaya kadar onu toprağa gömer." olarak değişmektedir, Nesefî, s. 74.

81 Anlaşıldığı kadarıyla Nesefì'de Meymûniyye olarak zikredilen firka, görüşleri eksik nakledilerek 
Beşinci grup Cehmiyye veya Muattıliyye'dir. Bunlar Allah'ın bütün sıfatlarını reddederler. Onlara göre Allah şey olmayıp, insanın işlediği hayır ve şer, İman ve Kuran mahlûktur. Bu mezhebin on bir alt koluna gelince, bunlar sırasıyla Merîsiyye, ${ }^{82}$ Merfiyye, ${ }^{83}$ Zenâdıka, ${ }^{84}$ Harkiyye, Mahlûkiyye, Fâniyye, Lağviyye, ${ }^{85}$ Vâkıfıyye, Kabriyye, Münkiriyye ve Râveniyye'dir. ${ }^{86}$

Altıncı ve son mezhep, Mürciyye veya Mübârekiyye'dir. Bu mezhebin temel iddiası, inandıktan sonra, kötü amellerin (seyyiât) zarar veremeyeceğidir. ${ }^{87}$ Mezhebin on bir alt firkasına gelince, bunlar sirasıly Sebbebiyye, ${ }^{88}$ Râciyye, Sârikiyye, Mübârekiyye/Hamzaviyye, Beyhesiyye, Dâsiyye, Muatt1liyye, Müşebbihiyye, Haşeviyye, Eseriyye ve Bidiyye'dir. ${ }^{89}$

Netice olarak İmam Mâturîdîye ait olmadığı anlaşılan bu kısa risale gerek içerik, gerek biçim yönünden Hanefî-Mâturîdî gelenek içerisinde yer almaktadır. Tamamen reddiyecilik mantı̆̆ıyla kaleme alındığı gözlenen risalen fırkalara dair araştırmacılara yeni bir şey sunmaz. Fırkalara dair bilgiler, soyutlamacı bir mantıkla tarihsel bağlamdan koparılarak, anonim biçimde

Hilmûniyye olarak değişmiştir. Metinde Hilmûniyye'nin. "imametin peygambere mahsus olmasından dolayı, bu ümmetin imamet hakkı olmadığını" iddia ettiği belirtilir. Hâlbuki Nesefî'de "Bir İmam olmadan bu ümmetin kurtuluşa eremeyeceği, bu imamında kendilerinin razı olacağı biri olması gerektiğini” savunan bir fırka olarak zikredilir. Dolayısıyla anlam tamamen değişmektedir. Aslında Arapça dil yapısı göz önünde bulundurulduğunda, iki yerde de aynı fırkadan bahsedildiği, fakat birtakım imla yanlışlarından dolayı bu farklılaşmanın ortaya çıktığı anlaşımaktadır. Bkz. BG, vr. 7a.; Nesefï, 78.

82 BG'de Merîsiyye hakkında zikredilenler Nesefî ile tamamen çelişmektedir. Şöyleki Nesefî’ye göre Merîsiyye fırkası Allah'ın İlim, Kudret, Meşiet ve Yaratma olmak üzere dört sıfatı dışında bütün sıfatlarının mahlûk olduğunu iddia ederken (s. 106), BG'de Allah'ın bu dört sıfatının mahlûk olduğu zikredilmektedir, vr. 7a.

83 Bu firkanın temel görüşü Allah’ın bir haddi ve mekânı olduğudur, BG, vr.7a. Ancak bu ifade Cehmiyye'nin genel görüşü dikkate alınırsa şüpheyle karşılanabilir. Nesefî’de Mültezikiyye olarak geçen firka ise Allah'ın haddi ve mekânı olup olmadığg hususunda görüş bildirilemeyeceğini öne sürmektedir, Bkz. Nesefî, s. 106.

84 Burada Zenâdıka olarak geçen fırka ile Nesefî'deki Vâridiyye, aynı fırkayı ifade etmektedir. Çünkü her iki fırkaya nispet edilen görüşlerin aynı olması yanında Nesefîdeki Zenâdıka fırkasının görüşleri çok daha farklıdır, $B G$, vr.7a; Bkz. Nesefî, s. 107-108.

85 Muhtemelen Nesefî'de Gayriyye olarak zikredilen fırkadır, BG, vr. 8b; Nesefî, s. 111.

86 Münkiriyye ve Raveniyye'nin her ikisi de aynı fikirleri savunan fırkalar olarak verilmektedir. $B G$, vr. 8a. Şunu da zikretmek gerekir ki, Nesefî'de Cehmiyve başlı̆̆ı altında zikredilen Lafziyve firkası $B G$ 'de ne ismen ne de görüş olarak geçmektedir.

$87 B G$, vr. 8a.

88 Nesefî'de Sâyibiyye olarak geçer. Fırkanın görüşleri dikkate alındı̆̆ında, doğrusunun bu tabir olduğu söylenebilir. Çünkü Nesefîdde “Allah'ın insanları dilediği şeyleri yapmalarında serbest buraktığı (sey-ye-be)", şeklindeki ifade, daha sonraki cümlelerin anlamına daha uygun düşmektedir (s. 115). Nitekim BG'de geçen (seb-be-be) fiili anlamlı bir cümle oluşturmada problem doğurmaktadır, vr. 8a.

89 Sârıkiyye, Mübârekiyye, Dâsiyye ve Muattıliyye Nesefî’de geçmeyen firkalardır. Ayrıca her iki eserde de ismi geçen Bidiyye fırkası sadece isim yönünden benzeşmektedir. Sahip oldukları görüşler yönünden farklı fırkaları ifade etmektedirler. $B G$, vr. 8b-9b; Nesefî, s. 133. 
verilmiştir. Bu durum söz konusu geleneğe ait tipik bir yaklaşımı ifade eder. Diğer yandan, Nesefînnin son derece özetlenmiş kötü bir kopyası izlenimi veren risalede, Harûriyye fırkası örneğinde olduğu gibi birtakım fırka isimlerinde bariz istinsah hataları yapılmıştır.

\section{Tezkiretu'l-Mezâhib}

Hanefî Fırak geleneği içinde yer alan bir diğer eser, İbnu Serrâc adında birisi tarafından "Tezkiretü'l-Mezâhib adıyla kaleme alınmış muhtemelen VI/XI. asra ait fırak çalışmasıdır. Öncelikle yazarın Gazali (ö. 505/1111)'den bahsediyor olması, ${ }^{90}$ onun en erken V/XI. asrın son çeyreğinde yaşamış olabileceği ihtimalini taşısa da, Fığlalı'nın da belirttiği üzere ${ }^{91}$ eserin yazarı büyük bir ihtimalle VI/XII. veya VII/XIII. asırda yaşamış olmalıdır. Eserin yazarı hakkında, ismi dışında, herhangi bir bilgi bulunmaz, ancak, eserin hemen başında yazarın hakikatin Ehl-i Sünnet ve'l-Cemâat yolu olduğunu belirten ifadeleri genel anlamda onun mezhebi kimliğini ortaya koymaktadır. ${ }^{92}$ Yazarın "imanın tant$m i$ " meselesinde ortaya koyduğu yaklaşımı onun Hanefî-Maturîdî bir çevreden geldiğini göstermektedir. Nitekim eserin genel hacmi göz önünde bulundurulduğunda, iman ile ilgili açıklamaya geniş yer verilmesi, İmân ve İslâm'ın aynı olup olmadığı hususundaki en doğru açılamanın İmam Mâturîdîye ait olduğunun belirtilmesi ${ }^{93}$ yazarın Mâturîdî kimliğini ortaya koymaktadır.

Eser yedi bölümden (ebvâb) oluşmaktadır. İlk bölüm "Ehl-i Sünnet ve'lCemâat'in Üzerinde Birleştiği Meseleler" başlı̆̆ altına verilmiştir. Bu bölümde öncelikle Sünni olmanın şartları Abdullah b. Abbas'tan naklen verilmiştir ki, bunlar Ehl-i sünnet mezhebinin temelini oluşturmaktadır. ${ }^{94}$ Bu mezhebin dışında kalan firkalar, asıl olarak altı gruba ayrılmıştır. Bunlar Râfıziyye, Hâriciyye, Cebriyye, Kaderiyye, Cehmiyye ve Mürcie'dir. Bunlar da kendi içinde on ikişerli alt gruplara ayrılır ve toplam firka sayısı yetmiş ikiye tamamlanmış olur.

İkinci bölümden itibaren daha önce zikredilen altı asıl fırka ve alt kollarından bahsedilir. Burada izlenen yöntem kısaca şöyle özetlenebilir: Önce-

90 TM, s. 121.

91 Yazarın yaşadığı dönem ve kimliği hakkında bkz. Fı̆̆lalı, Ethem Ruhi, Burdur Kütüphanesi'nde Bulunan Bir Risale "Tezkiretü'l-Mezâhib", AÜiİED, Sayı: 2, (1975 ), s. 99.

92 TM, s. 119.

93 Burada yazar Gazali'den bahsederek, aslında onun bu husustaki görüşünün imam Mâturî̀î ile aynı olduğu belirtir. Böylece onun mezhebi anlamda Eşarilere karşı yumuşak bir tavır içinde olduğu söylenebilir, bkz. s. 121-22.

94 Bu şartlar toplam sekiz tane olup kısaca şu şekilde özetlenebilir. 1) Dört halifeyi hilafet sırasına göre birbirine üstünlüklerini (tafdîl) kabul etmek. 2)Beytu'l-Makdis ve Kabe'yi yüceltmek (tazî$m)$, 3) Meshlerin üzerine mesh etmek, 4) Aşere-i Mübeşşere'dıştnda herhangi bir kimsenin kıyametteki durumu hakkında kesin bir hükümde bulunmamak. 5) İyi veya kötü herkesin arkasında namaz kılmak. 6)Hayır ve şerrin Allah'tan olduğuna inanmak, 7) Ehl-i Kıble'den ister iyi, ister fasık veya itaatkâr olsun herkesin cenaze namazını kılmak. 8) Adil veya zalim olsun iktidara (ulû'l-emr) itaat etmek, s. 120-21. 
likle asıl fırkaya ait on iki grubun isimleri zikredildikten sonra bunların üzerinde ittifak ettikleri meseleler verilir. Daha sonra her firkanın on iki alt grubunun görüşleri, "firkaların ihtilafa düştükleri meseleler" başlı̆̆ı altında sıralanır. Buradaki açıklamalar çok kısa olup çoğu zaman birer cümleyi aşmaz.

İkinci bölümde yazar Rafızî fırkaları ele alır. Bunlar sırasıyla Aleviyye, Eydiyye, Şîa, İshâkiyye, Zeydiyye, Abbâsiyye, İmâmiyye, Nâvusiyye, Mütenâsihiyye, Lâiniyye, Râciyye ${ }^{95}$ ve Müterabbisiyye'dir. Bu furkalar, ismen Nesefî ve $B G$ 'dekilere çok yakın olmakla birlikte, sahip olduları görüşler yönünden benzerlikler daha azdır. Burada Eydiyye olarak geçen fırka, Nesefî'de Emriyye, $B G^{\prime}$ 'de ise Âmiriyye olarak zikredilir. ${ }^{96}$ Bununla birlikte, bu üç ayrı firka aynı görüşü sahiptir ve muhtemelen tek bir fırkayı ifade etmektedirler. Ancak aynı ismi taşıyan fırkalara nispet edilen görüşler noktasında aynı şeyi söylemek mümkün değildir. Bunlar arasında Şîa, Zeydiyye, İmâmiyye, Nâvusiyye ve Müterabbisiyye fırkaları Nesefî ve $B G$ 'de zikredilenlerden farklı görüşleri savunmaktadırlar. ${ }^{97}$

Üçüncü bölümde Hâricî fırkalardan aynı yöntem üzere bahsedilmektedir. Öncelikli olarak bu fırkaların isimleri verildikten sonra ${ }^{98}$ Hâricîliğin üzerinde ittifak ettiği hususlara değinilir. Bu hususlar kısaca şunlardan oluşmaktadır: 1) Cemaat hak üzere değildir, 2) Günah işlediğinden dolayı Ehl-i Kıble küfre girmiştir, 3) Zalim yöneticiye itaat edilmemesi gerekir, 4) Muaviye hakikat üzeredir..$^{99}$

Eserde Eciyye olarak zikredilen fırka, Nesefî ve $B G$ 'de ismen zikredilmemiş olmakla birlikte, benzer görüssleri savunan Ahnesiyye ile aynı fırka olma ihtimali yüksektir. Şöylek ki bu firkalardan Eciyye "kişinin öldükten sonra

95 Metinde Râcuyye şeklinde verilir.

96 Bkz. Nesefî, s. 79; TM, s. 123; BG, vr. 5a.

97 Bu farklılıkları zikretmek gerekirse; Nesefî ve $B G$ 'de Şîa, "Hz. Peygamberin, hilafeti Hz. Ali’ye vasiyet ettiğini öne süren bir fırka" olarak zikredilirken, elimizdeki eserde "Ali'yi başkasından çok sevmeyenin küfrüne hükmeden bir firka” olarak geçmektedir (Bkz. Nesefî, 80; BG, vr. 5b; $T M$, s. 124). Zeydiyye, Nesefî (s. 83) ve $B G^{\prime}$ de (vr.5b). Hüseyin soyundan olmayanın arkasında namaz kılınamayacağı öne sürülürken, burada imametin Ali soyundan başkasına ait olamayacağı belirtilerek çerçeve daha geniş tutulmaktadır (TM, s. 124). Imâmiyye, ilk iki eserde imametin ancak Hüseyin soyundan kişilere ait olacağını iddia eden bir fırkadır. Söz konusu eserde ise günahkârın arkasında namaz kılınmasını reddeden ve hilafetin Haşimoğullarına ait olduğunu öne süren bir firkadır (Bkz. Nesefî, s. 82; BG, vr.5b; TM, s.124). Nâvusiyye firkası, Nesefî ve $B G$ 'de (Fârisiyye şeklinde) Hz. Ali'nin Hz. Peygamberden sonraki en üstün şahsiyet olduğunu iddia eden bir firka olarak zikredilirken (Nesefî, s. 81; $B G$, vr.5b), TM'de kendisine daha farklı bir görüş isnad edilerek kendisini başkasından üstün gören kimsenin bu fırka tarafından kâfir olarak görüldüğü belirtilir (TM, s. 124). Müterabbisiyye, ilk iki eserde Nisaburlu bir şahsın mehdiliğini iddia ederken (Nesefî, s. 56; $B G$, vr.6a), sonuncuda imama karşı isyan edip savaşmayı onaylayan bir fırka görünümündedir (TM, s. 125).

98 Bu firkalar sırasıyla Ezrakiyye, İbâdiyye, Sa'lebiyye, Hâzımiyye, Halfiyye, Kûziyye, Kenziyye, Mutezile, Meymûniyye, Muhakkimiyye, Eciyye ve Şemrâhiyye'dir (TM, s. 126).

99 TM, s. 126. 
kıyamet gününe kader salih amel işleyemeyeceğini" savunurken, ${ }^{100}$ Ahnesiyye öldükten sonra kişiye iyilik veya kötülüğün ulaşamayacağını öne sürerek $^{101}$ neticede aynı görüşü ileri sürmektedir. Buradan hareketle iki farklı isim altında verilen firkaların aslında tek bir fırka olduğu, söz konusu farklılaşmanın muhtemlen bir istinsah hatasından kaynaklandığı söylenebilir. Bu firka dişında diğer Hâricî fırkalar isim yönünden Nesefî ve $B G$ 'de zikredilen Hâricî fırkalarla tamamen uyuşmaktadır. Savundukları görüşler noktasında İbâdiyye, Mutezile, Meymûniyye hariç diğer fırkaların genel anlamda benzeştiği söylenebilir. ${ }^{102} \mathrm{Bu}$ bölümde kayda değer en önemli husus Mutezile firkasının diğer fırkalar göre alışılmışın dışında çok daha ayrıntılı bir biçimde ele alınmasıdır. ${ }^{103}$

Dördüncü bölümde Cebriyye'nin on iki fırkasından bahsedilir. Burada Furûiyye, Mutmainniyye, Keselliyye, Fikriyye ve Habsiyye firkaları ismen Nesefí'de zikredilenlerden farklı olmakla birlikte, sahip oldukları görüşler dikkate alındığında Mutmainniyye, Keselliyye ve Fikriyye firkalarının sırasıyla Nesefi'deki Menâniyye, Kesbiyye ve Bekriyye firkaları oldukları anlaşılmaktadır. ${ }^{104}$ Furûiyye firkasının hangi görüşe sahip olduğu zikredilmediğinden bu firka hakkında kesin bir şey söylemek mümkün olmamakla birlikte, Mefrûğiyye fırkası olma ihtimali yüksektir. Bunun yanında Habsiyye firkası, gerek isim gerekse sahip olduğu görüş yönünden daha önceki eserlerde geçen firkalardan hiçbirine benzememektedir. ${ }^{105}$ Dolayısıyla zikredilen son iki fırka dışında diğer firkaların Nesefî ile aynı olduğu söylenebilir.

100 TM, s. 128.

101 Nesefî, s. 76; $B G$, vr.6b.

102 Ezrakiyye ile ilgili olarak TM'de Nesefî ve $B G$ 'de olduğu gibi vahyin sona ermesinden bahsedilmekle birlikte, burada diğerlerinden farklı olarak ru'ya-yı sâdıka tabiri kullanılır. Bunun yanında İbâdiyye hakkında zikredilenler Nesefi'deki ilk cümlenin bir özeti mahiyetindedir. Nesefi’deki söz konusu cümle "İman, söz, amel ve sünnettir." şeklindeyken, TM'de “İman salih amel olmadan tamamlanmaz" şeklinde geçmektedir (TM, s. 126). Yine Nesefî ve BG'de Sa lebiyye firkasının iyi ameller hususunda kaza ve kaderi reddettiği belirtilirken (Nesefi, s. 70, BG, vr.6a), TM'de bu fırkanın imanın kaza ve kader ile yaratılmadığını öne sürdüğünden bahsedilir (TM, s. 126). Nesefî ve TM'de geçen Meymûniyye firkası hakkında zikredilenler birbirinden tamamen farklıdır. Öyleki, Nesefî'de fırka "Ümmetin İmam olmadan kurtuluşa eremeyeceğini”" öne sürerken ki bu, imamet bahsiyle alakalı bir husustur, TM'de "amelsiz imanın batıl olacağı" dile getirilmektedir. Burada söz konusu olan husus ise iman ile ilgilidir. Dolayısıyla bu iki firkanın aynı olup olmadı̆̆ hakkında kesin bir şey söylemek mümkün değildir. Eğer bu iki fırkanın tek bir fırka olduğu kabul edilirse, bu durumda yazarların aynı fırkanın iki farklı konudaki görüşünden bahsettikleri söylenebilir, Nesefî, s. 78; TM, s. 128.

103 Nesefî ve $B G$ 'de Mutezile fırkası Ali ve Muaviye'nin hilafeti hakkında şüpheye düşerek ondan teberri eden bir fırkadır. TMPdeki fırkaya gelince bu, bilinen Mutezile fırkasıdır, Nesefî, s. 77; $B G$, vr.6 b-7a; $T M$, s. 127.

104 Bu isim farklılığı muhtemelen imla hatasından kaynaklanmaktadır, TM, s. 129-30; Nesefî, s. 100, 104.

105 Burada Habsiyye firkası “Tevrat'ı inkar eden” bir firka olarak zikredilmektedir (TM, s. 130). 
Kaderiyye'nin ele alındığı beşinci bölümde daha önce olduğu gibi, on iki alt fırka zikredildikten sonra ${ }^{106}$ fırkaların sahip oldukları ortak görüşler dile getirilir: 1) Şerrin insanlara göre iman olmasına karşılık, Allah katında küfür olması mümkündür, 2) Cenaze namazı caiz değildir, 3) Misak, hayır ve şerrin takdiri Allah'tan değildir, 4) Kişilerin Allah katında mümin ya da kâfir olduğu bilinemez. ${ }^{107}$

Menziliyye hariç, zikredilen fırka isimleri, imla hatasından kaynaklanan bazı farklılıklar dikkate alınmazsa, ${ }^{108}$ daha önce geçen eserlerdekilerle aynıdır. Fırkaların savundukları görüşlere gelince, genel olarak Nesefî'deki ifadelere yakın şeyler ileri sürmektedirler. ${ }^{109}$ Bununla birlikte burada firkaların görüşleri birkaç kelimeyi geçmeyecek şekilde çok kısa olarak verilmiştir. Öyle ki cümlelerin bir kısmı metinden düşmüş veya yarısında kesintiye uğramış izlenimi vermektedir. Nitekim Zevidiyye fırkası ismen zikredilmekle birlikte görüşleri zikredilmemiştir. Son sırada zikredilen Menziliyye fırkasına nispet edilen görüş dikkate alındığında, onun Nesefî'deki Mutezile ile aynı firka olduğu söylenebilir. ${ }^{110} \mathrm{Bu}$ bölümde ilginç olan noktalardan birisi de Şiî bir fırka olan Keysâniyye'nin Kaderiyye içerisinde zikredilmesidir. ${ }^{111}$

Altıncı bölüm Cehmiyye fırkalarına tahsis edilmiştir. ${ }^{112}$ Bunların üzerinde ittifak ettiği görüşler, 1) İman dille değil, kalbledir, 2) Kevser, Münker Nekir'in sorgulaması ve ölüm meleğinin inkâr edilmesidir. ${ }^{113}$ Burada zikredilen fırkalardan Müterâbısiyye, Müterâfiizye ve Râzıkiyye ismen Nesefı'den farklıysa da, ilk ikisine nispet edilen görüşler Nesefî'de geçen Merîsiyye ve Multezikiyye fırkalarınkine yakındır. ${ }^{114}$ Râzıkiyye fırkası ise daha önce tesadüf edilmeyen bir firkadır. ${ }^{115}$

Yedinci ve son bölüm Mürcie fırkalarına ayrılmıştır. Bu bölümde Mürcie'nin ortak görüşleri zikredilmez ve doğrudan alt fırkaların isimleri verilir. ${ }^{116}$

106 Bu firkalar sırasıyla Ahmediyye, Seneviyye, Keysâniyye, Şeytâniyye, Şerîkiyye, Vehmiyye, Zevidiyye, Nâsikiyye, Butriyye, Nâstiiyye, Nazzâmiyye ve Menziliyye'dir, TM, s. 130.

107 TM, s. 130-31.

108 Şerîkiyye, burada Şerifiyye; Muteberrie, Butriyve; Kâsttiyye ise Nâsttiyye şekline dönüşmüştür, bkz. s. $111,112$.

109 Bunlardan Ahmediyye, Seneviyye ve Vehmiyye'nin görüşleri Nesefi'dekilerden farklıdır.

110 Nesefíde Mutezile fırkası, Allah'ın hayrı insanlar için takdir ettiğini, ancak şerri takdir edip etmediği hususunda hiçbir şey söylenemeyeceğini öne sürerken (s. 88); söz konusu eserde Menziliyye, şerrin Allah'ın takdiri ile olup olmadığının bilinemeyeceğini öne sürer (s. 132).

111 TM, s. 131.

112 Bu fırkalar sırasıyla Muattıliyye, Müterâbısiyye, Müterâfiiiyye, Vâridiyye, Harkiyye, Mahlukiyye, Gayriyye, Fâniyye, Râzıkiyye, Lafziyye, Kabriyye ve Vâkıfiyye'dir (TM, s. 132).

113 TM, s. 132

114 Krş. TM, s. 133; Nesefî, s. 106.

115 Râzıkiyye firkasının görüşleri; miracın bedenen değil ruhla olması, Allah'ın her halükarda görülemeyeceği, Kiyamet alametlerinin reddedilmesi ve âlemin kadim olduğudur, T.Mezahib, s. 134.

116 Bunlar sırasıyla Târikiyye, Şâibiyye, Râciyye, Şâkkiyye, Beyhesiyye, Ameliyye, Menkûsiyye, Meşîiyye, Eseriyye, Bidiyye, Müşebbihe ve Haşeviyye'dir, TM, s. 114. 
Mürcie'ye nispet edilen fırkalar daha öncekilerde olduğu gibi, Meşiiyye hariç, ${ }^{117}$ ismen Nesefî'dekilerle tam bir benzerlik gösterir. Bununla birlikte Râciyye, Şâkkiyye, Menkûsiyye ve Bid'ıyye gibi bir kısım fırkalara nispet edilen fikirler Nesefî ile tamamen tezat teşkil eder. ${ }^{118}$ Eserden yola çıkarak bu farklılığın sebeplerini tespit et-mek mümkün değildir. En fazla söylenebilecek ihtimal onların başka bir kaynaktan alınmış olduklarıdır.

Yazar bu yetmiş iki fırka faslını bitirdikten sonra İmam Ebû Kâsım'dan ${ }^{119}$ rivayetle yedi ayrı fırka ismi daha zikreder. Bunlar Kerrâmiyye, Dehriyye, Sâbiliyye, İbâhiyye, Bâtıniyye, İbrâhimiyye ve Eşariyye'dir. Burada Eşariliğin Mutezile'nin bir alt kolu olarak zikredilmesi ilginçtir. Ayrıca İmam Azam'ın Fikhu'l-Ekber'inden naklen Kerrâmiyye'nin bir alt kolu olarak Cismiyye adında bir başka fırkadan bahsedilir. ${ }^{120}$

\section{4. el-Fırak'ul-Mufterika Beyne Ehli'z-Zeyğ ve'z-Zendeka}

Hanefî-Mâturîdî gelenek içerisinde değerlendirilebilecek bir diğer çalışma da Ebû Muhammed Osman b. Abdillah el-Irâkî adında Hanefî yazar tarafından kaleme alınmış olan el-Furaku'l-Mufterika Beyne Ehli'z-Zeyğ ve'zZendeka adlı eserdir. Merhum Yaşar Kutluay tarafından 1961 yılında neşredilen ${ }^{121}$ eserin yazarı hakkında yeterince bir şey bilinmemektedir. Ancak naşirin de belirttiği gibi yazarın Tük olma ihtimali hayli yüksektir. Verilen isnatta iki Türk ismi geçmekte olup ${ }^{122}$ naşir, Osman b. Abdullah'ı Arap olmayan bir şahsiyet olarak kabul eder. ${ }^{123}$ Şöyle ki yazarın hocalarından Şemseddin Ömer b. İbrahim b. Osman, Türk (et-Türkî) asıllıdır. Ayrıca râvi zincirinde ikinci defa bir Türk ismi olan "Yenâl/Yinâl" geçmektedir ki bu durum yazarın Türk olma ihtimalini artırmaktadır.

Yazarın Hanefi nisbesi göz önünde bulundurulursa, onun, Hanefî-Mâturîdî fikir çevrelerinde bulunduğuna hükmedebiliriz. Bu ilk kanaat, sadece onun Ebû Hanîfe'ye, iki defa el-İmâm el-A'zam olmak üzere, defaatle yaptı̆̆̆ atıflarla

117 Nesefíde Müstesniyye olarak geçmekle birlikte, ikisi de aynı fikirleri savunmaktadır, bkz. Nesefî, s. 120, 135.

118 Mesela Nesefi'de Râciyye firkası "hem itaat edene, hem de isyan edene itaatkâr denemeyeceği gibi isyankâr da denemeyeceğini” öne sürmektedir. TM'te ise itaat ve isyan edene itaatkâr ve isyankâr denebileceği" belirtilir Yine Mankûsiyye, Nesefî'de "imanın artıp çoğalacağını" iddia ederken TM'de tam tersi bir fikir öne sürülür, Nesefî, s. 116, 119; TM, s. 135.

119 Buradaki ifadelerden yola çıkarak yazarın, Ebû'l-Kâsım künyesiyle kimi kastettiğini tespit etmeye çalıştıysak da, neticede kesin bir kanaate varamadığımızı üzülerek söylemek durumundayız.

120 TM, s. 136-38.

121 Nşr. Yaşar Kutluay, Ankara Ünivesitesi İlahiyat Fakültesi Yayınları, no. 32, Ankara 1961. Bundan sonra eserden $F M$ olarak bahsedilecektir.

122 (Muhtemelen yazarın hocası olan) Ömer b. İbrahim b. Osman et-Türkî ve İsmail b. Yinâl elMahbûbî el-Mervezî. FM, s. 6.

$123 F M$, s. 1. naşirin giriş kısmından. 
değil, ${ }^{124}$ fakat aynı zamanda eserin baş tarafında ehlü's-sünnet ve'l-cemaat'e dair açıklamalarında ortaya koyduğu mezhebi duruşuyla da doğrulanmaktadır. Mesela, insanın kötü fillerinin Allah'ın irâdesinin (meşie, irâde, takdir) dışında görülmesinin reddedilmesi Mutezile'ye yönelik bir tavır iken, ısrarla ihtiyâr ifadesinin kullanılması da onun insan hürriyeti hususunda Eşârilerden faklı tavır alışını gösterir. ${ }^{125}$

Yazarın firkaları ele alış biçimi genel olarak Nesefi'yle benzer özelliklere sahiptir. Daha önceki çalışmalarda olduğu gibi ehl-i dalâleti altı ana gruba ayırır. Bunlar sırasıyla Nâsibiyye, Râfiza, Cebriyye, Kaderiyye, Müsebbibe ve Muattıla'dır. Bu bilgilerden sonra yetmiş firka hadisinin bahsine geçer. Ehl-i Sünnet ve'l-Cemaat'in ne olduğunu bu altı ana mezhebe kıyasla açıklar. ${ }^{126}$ Bununla birlikte yazar ilk üç ana grubu on iki alt firkaya ayırarak kendisinden önceki Hanefî-Mâturîdî taslağa uygun davranırsa da, geriye kalan diğer üç ana grubun alt firkalarını tasnif ederken, bu kurala yeterince uyduğu söylenemez ve muhtemelen Hanefî-Mâturîdî firka geleneği dışında birtakım kaynaklardan beslendiği anlaşılmaktadır. Böylece yetmiş iki sapkın fırka sayısı aşılmış olur.

Bu altı ana fırkanın haricinde "Kâfirler ve Alt Gruplarının Zikrine Dair (Fî Zikri'l-Kufr ve Asnâfihim)" başlığı altında eserde ayrı bir bölüm daha yer almaktadır ki bu, söz konusu fırak geleneğinde daha önce karşılaşılmayan bir durumdur. Bilhassa "Melâhide ve Bâtıniyye" alt başlığında eserin yaklaşım tarzı son derece farklılaşır. Daha önce görülmemiş bir biçimde Bâtıniliğin ortaya çıkışı, farklı meselelerdeki görüşleri, davet aşamaları gibi hususlar ayrintilı olarak verilir. ${ }^{127}$

Yazar fırkaların görüşlerini ele almaya Haricilikle başlar. Burada dikkati çeken husus yazarın Hariciliği ifade etmek için Nâsıbiyye ismini tercih etmesidir. Bu, daha önce ele aldığımız eserlerde karşılaşmadığımız bir isim olması açısından kayda değerdir. Sonra bu asıl mezhebi ifade etmek için kullanılan diğer isimleri ve bu isimlerin veriliş gerekçelerini zikreder. Bunlar Harûriyye, 'Acâride, Hâriciyye ve Mârikiyye'dir. Bu, diğer eserlerde karşılaşmadığımız bir durum olup belki de yazar, yetmiş üç fırka tasnifinin neden olduğu bir zorlamadan dolayı bu yola başvurmuştur. Yazara göre bu fırkanın görüşlerinin aslı, Hz. Ali'den teberri ederek onu tekfir etmeleri, günahkâr ve namazı terk edenleri küfürle itham etmeleridir ki bu sayılan hususlar, Hâricî zihniyetin tipik özelliklerini yansıtmaktadır. ${ }^{128}$

124 FM, s. 8, 54, 55, 66, 89.

125 FM, s. 8, 17; krş, Lewinstein, Studies, s. 168.

126 FM, s. 9-10.

127 FM, s. 98 vd.

128 FM, s. $10-11$. 
$\mathrm{Bu}$ ana gruptan ortaya çıkan on iki alt fırkaya gelince bunlar, Ezrakiyye, İbâdiyye, Hamziyye, Halîfiyye, Kûziyye, Kenziyye, Şemrâhiyye, Ahnesiyye, Muhakkime, Meymûniyye, Hâriciyye ve Saltiyye'dir; ayrıca bu gruba Şeybâniyye ve Yezidiyye fırkası da eklenir ki böylece sayı on dörde yükselmiş olur. ${ }^{129}$ Muhtemelen bu iki fırka, daha önceki eserlerde olmayıp daha sonra ortaya çıkan fırkalardandır. ${ }^{130}$

Öncelikle belirtmek gerekir bu eserde daha önceki Mürcî̂-Hanefî Fırak eserlerinden farklı diyebileceğimiz bir yaklaşım izlenmiştir. Şöyle ki Hâricî fırkalardan Ezârika'dan bahsedilirken, bilhassa dikkat çeken husus, diğer eserlere nazaran bu fırkanın görüşlerinin daha ayrıntılı bir şekilde ele alınmasıdır. Ayrıca fırkaların nispet edildiği şahısların isimleri zikredilerek bu gelenekte nadir görülen bir yaklaşım içine girilmiştir. Fırkaya nispet edilen görüsslere gelince, yazarın burada zikrettikleri diğer eserlerden farklıdır. Fırkanın görüşleri beş madde altında verilir. Bunlar kısaca 1) Kendilerine katılmayan kâfirdir. 2) Kazf cezası muhsan kadına vacip; ancak muhsan erkeğe vacip değildir, 3) Muhsan recmedilmez, 4) Her türlü hırsızlıktan dolayı, kol kesmek vaciptir, 5) Her ne şekilde olursa olsun, devlet başkanına itaat etmek gerekir, onun emrine aykırı davrananın kanı helaldir. ${ }^{131}$ Fırkanın bu görüşlerinin zikredilmesinden sonra bunlara teker teker cevap verilir. Burada yazar cevap faslını diğerlerine çok daha uzun tutar. Bununla birlikte yazarın fırkaların görüşlerim zikrettikten sonra onlara cevap vermesi, yöntem olarak Nesefî ve $B G$ 'nin yaklaşımına benzemektedir.

İbâdiyye fırkası hakkında yazarın zikrettikleri, daha önce Nesefî ve $B G$ 'de Ezrakiyye ve İbâdiyye için zikredilenlerin toplamını oluştururken, TM'de sadece Ezrakiyye için kullanılır. Ayrıca FM'de kullanılan ifadeler daha anlaşılır olup bir bütünlük içinde verilmiştir. ${ }^{133}$ Eserde Hamziyye başlığ 1 altında zikredilen fırkanın iddiaları, diğer eserlerde Hâzımiyye olarak verilen firkanın görüşlerini andırmaktadır. ${ }^{134} \mathrm{Bu}$ açıdan, bu iki fırkanın tek bir fırka olduğu

129 FM, s. 11.

130 Şehristânî (ö. 548/1153), Yezid b. Üneys'e nispeten Yezidiyye adında Hârici bir firkadan bahseder, bkz. Şehristânî, Ebû'l-Feth Muhammed b. Abdilkerîm, el-Milel ve'n-Nihâl, Beyrut 1948, I/158-59.

131 FM, s. 12.

132 FM, s. $12-14$.

133 Bu fırkanın "kimse için mümin veya kâfir demiyoruz" ifadeleri, benzer biçimde Nesefî̀de İbâdiyye için kullanılırken, ondan sonra gelen "Vahiy kesildiğinden, Ebû Bekir ve Ömer vefat ettiğinden dolayı bize hakikatleri açıklayacak, mümini kâfirden ayıracak kimse kalmamıştır.” ifadesi de Ezrakiyye için kullanılır. BG için de benzer bir durum söz konusudur (Krş. FM, s. 14; $B G$, vr.6a; Nesefî, s. 69). Bunun yanında FM'de geçen ifadeler, yaklaşık ifadelerle TM ve $M M$ 'de sadece Ezrakiyye için kullanılır, TM, s. 126; MM, s. 14.

134 FM'de daha çok tevhidin meçhul olup ulaşılamayacak bir şey olduğu söylenirken, diğer eserlerde, daha çok imanın meçhuliyetinden bahsedilir. Krş. FM, s. 16; Nesefî, s. 71; BG, vr. 6a; TM, s. 127. 
söylenebilir. Bunun yanında Halîfiyye, Kûziyye, Kenziyye, Ahnesiyye, Muhakkime fırkaları diğer eselerde zikredilen fırkalarla aynı görüşlere sahipken, Meymûniyye firkası sadece Nesefî'deki ile benzeşir. Ayrıca Şemrâhiyye ve Hubbiyye tek bir fırka olarak verilir. ${ }^{135}$ Daha önce zikri geçmeyen Şeybâniyye ve Yezidiyye fırkaları kadınların imametini mümkün gören iki fırkadır. ${ }^{136}$

Yazar Hâricî fırkalardan bahsederken, bunlardan bir kısmını Ezrakiyye, İbâdiyye gibi nispet edildikleri şahıslar ve temel görüşleriyle birlikte vererek, diğer bir kısmını da anonim olarak sadece görüşlerini dile getirir. Akabinde Ehl-i Sünnet ve'l-Cemaatin her birine yönelik cevabı gelir ${ }^{137}$ ki bu durum söz konusu fırak geleneğinin tipik bir özelliğidir.

Daha önce incelenen eserler dikkate alındığında, Haricilerden birçok fırkanın aynı isim altında zikredildiği görülür. Yazarın burada izlediği yöntem firkaya nispet edilen görüşlerin zikredilmesinden sonra bunlara cevap verilmesi şeklindeyse de, önceki eserler göre çok daha uzun ve ayrıntılı bir açılamanın tercih edildiği görülür. Fırkalar hakkında verilen bilgiler çok daha düzenli ve anlaşılır bir biçimde verilir. Öyle ki bu eserlerde serpiştirilmiş hâlde bulduğumuz bilgiler, burada adeta cemedilmiştir. Ayrıca yazarın fırkaların nispet edildiği şahısların isimlerini vermesi, eserin bir başka özgün yönüdür. ${ }^{138}$

İkinci sırada yazar Ravâfız'dan bahseder ve ayrıca aynı fırka için İmâmiyye, Gulât ve Zeydiyye tercih ettiği diğer isimlerdir. Bu firkanın dayandığı temel iddia, Ebu Bekir ve Ömer'i tekfir ederek onlardan teberri ederek sadece Ali'ye tevelli etmeleridir. ${ }^{139}$ Ravâfız'ın on iki alt fırkasına gelince, bunlar sırasıyla, Kâmiliyye, Gurâbiyye, Şerîkiyye, İshâkiyye, İmâmiyye, Zeydiyye, Sehâbiyye, Tenâsuhiyye, Lâiniyye, Sebâiyye, Mansûriyye ve Hattâbiyye olup ayrıca Mufavvıza ve Nisbiyye firkalarını da bu on iki alt fırkaya ekler. ${ }^{140}$

Bunlardan Kâmiliyye fırkası isim ve görüş olarak daha önce bahsi geçmeyen bir fırkadır. ${ }^{141}$ İkinci sırada Gurâbiyye fırkasından bahsedilir ki, bu daha önce 'Aleviyye olarak geçen fırkanın kendisidir. ${ }^{142}$ Ayrıca Şerîkiyye fırkası, Emriyye, Âmiriyye, Ebteriyye veya Eydiyye olarak geçen firkaya tekabül

$135 \mathrm{Bu}$ iki fırka her ne kadar tek bir fırka olarak verilmişse de, daha önce bu fırkalara teker teker nispet edilen görüşler burada zikredilmiştir, s. 20 .

136 FM, s. 28.

137 FM, s. 29

138 FM, s. 11-29.

139 FM, s. 30 .

140 FM, s. 31.

141 Burada Kâmiliyye, "Ali dâhil bütün sahabeyi tekfir eden” bir firka olarak zikredilir, s. 31, 32.

142 Her iki fırkada da öne çıkan görüş aslında nübüvvetin Ali'nin hakkı olduğu ancak Cebrail'in hatası sonucunda Hz. Peygambere verildiği” iddiasıdır, bkz. FM, s. 32; Nesefî, s. 79; BG, vr.5a; TM, s. 123. 
edereken; ${ }^{143}$ Sehâbiyye firkası ise Reci'iyye, Nisbiyye de Nâvusiyye şeklinde farklı isimlerle zikredilen firkaya delalet etmektedir. Diğer yandan İshâkiyye, Imâmiyye, Zeydiyye, Tenâsuhiyye ve Lấiniyye adlı firkaların da tek bir firka olma ihtimalleri son derece yüksektir.

Burada zikredilmesi gereken hususlardan birisi de standart firak eserlerinde Şia dendiğinde ilk akla gelen Sebeiyye fırkası ile birlikte Hattâbiyye, Mansûriyye ve Mufavvıza firkalarının bu gelenek içinde ilk defa bu eserde zikredilmiş olmasıdır. ${ }^{144}$ Bu noktada eserin yazılmasında daha farklı kaynaklardan, özellikle diğer fırak geleneklerinden faydalanıldı ̆̆ı anlaşılmaktadır.

Üçüncü asıl fırka olarak zikredilen grup Kaderiyye'dir. Kaderiyye'nin temel iddialarına ${ }^{145}$ cevap verildikten sonra on iki alt firkadan bahsedilir. Bunlar Aslahiyye, Vâsıliyye, Amriyye, Huzeyliyye, Hişâmiyye, Kâsıtiyye, İvaziyye, Seneviyye, Behâşimiyye, Ravendiyye, Hayyâtiyye, Nâkısiyye ve Nazâmiyye'dir. ${ }^{146}$ Aslahiyye'ye benzer bir fırka, ne ismen ne de görüş olarak daha önceki eserlerde geçmemektedir. Bu firkaya verilen diğer bir isim, ümmetten itizal etmesinden dolayı, Mutezile'dir. ${ }^{147}$ Yine Vâsıliyye-Amreviyye firkası için de Mutezile ismi kullanılır. Her ne kadar eserin baş tarafında fırkaya nispet edilen fikirler diğer eserlerde geçmiyorsa da, son kısımdakiler dikkate alındığında, ${ }^{148}$ bu firkanın Nesefîde Mutezile, ${ }^{149}$ BG'de Muğteziliyye, ${ }^{150}$ TM'de Menziliyye ${ }^{151}$ olarak geçen fırka olduğu anlaşılmaktadır. Huzeyliyye, Hişâmiyye ve İvâziyye fırkaları daha önce tesadüf edilmeyen firkalar arasında yer almaktadırlar. Her ne kadar Kâsttiyye fırkası öncekilere ismen benzese de farklı görüşlere sahip bir fırkadır. ${ }^{152}$

Seneviyye-Şerkiyye ${ }^{153}$ şeklinde çift isimle zikredilen fırka, daha önceki kaynaklarda sadece Seneviyye olarak zikredilen firkayla benzerlik gösterir. Bunun yanında daha önceki Şerikiyye fırkasının buradaki Şerikiyye ile ala-

143 Fırkalara aynı görüşün nispet edilmesinin yanında, eserde fırkanın bir diğer isminin de Emriyye olduğu belirtilerek bu durum teyit edilir, bkz. FM, s. 32, 33; Nesefî, s. 79; BG, vr.5a; TM, s. 123. 144 Ancak yazar Sebeiyye yerine Sebâiyye ifadesini kullanmıştır. FM, s. 40-43.

145 Kaderiyye'nin temel iddiaları; 1) İnsanın fiilinin yaratıcısının Allah değil, insan olması, 2) Küfür ve günah işlemede Allah'ın takdiri, meşieti ve iradesinin reddedilmesi, 3) Allah'ın sıfatlarının, ahirette görülmesinin inkârı, 4) İtaat veya isyanla sevap veya günah kazanılamayacağı (s. 44).

146 FM, s. 46.

147 FM, s. 46.

148 "Hayır ve taat Allah'ın meşietiyle olup şerr ne onun takdirindedir, ne de takdirinin dışındadır." FM, s. 47.

149 Nesefî, s. 88.

$150 B G$, vr.3a.

151 TM, s. 132 .

152 FM, s. 49-51.

153 Mecusiler gibi, iki yaratıcıya inandığı için Seneviyye; yaratmada Allah'a Şeytan'ı da ortak yaptıklarından dolayı Şerikiyye olarak adlandırılmıştır, FM, s. 55. 
kası olmadığı anlaşılmaktadır. ${ }^{154}$ Behâşimiyye fırkası ismen daha önce zikredilen firkalardan hiçbirine benzemez; ancak iddia ettiği görüşler dikkate alındığında, onun Nesefî'deki Müteberrie, TM’deki Bütriyye, BG'deki Müterebbiyye ile aynı fırkaya delalet ettiği anlaşılmaktadır. ${ }^{155}$ Ravendiyye'ye gelince, bu firkaya nispet edilen nesh meselesi diğer eserlerde farklı isimlerle geçen bazı fırkalara da nispet edilmekle birlikte, aslında bunların farklı meselelerden bahseden farklı firkalar olduğu rahatlıkla fark edilebilir. ${ }^{156} \mathrm{Bir}$ diğer önemli husus kaynaklarda Ebû'l-Hattâb'a nispet edilen Gulat firkalardan Hattâbiyye'nin bu gelenek içerisinde ilk defa burada zikredilmesidir. ${ }^{157}$

Cebriyye firkası dördüncü sırada ele alınan gruptur. Bu firka aynı zamanda -Mürcie ve Neccâriyye olarak da nitelenir. Bunların temel iddiası kişinin gerçek manada fiilinin olmadığıdır. ${ }^{158}$ Burada Mürcie'nin Cebriyye ile aynı fırka olarak zikredilmesi, diğer eserlerde daha önce karşılaşılmayan ilginç bir durumdur. Bu durumun gerekçesine dair herhangi bir bilgi verilmediğinden ötürü bir tahminde bulunmak son derce zordur. Mürcie'nin alt grupları olarak geçen on iki fırka keza genel olarak Cebrî firkalar olarak zikredilen firkalardır. Bunlar sırasıyla Muztarriyye, Acziyye, Mefrûğiyye, Neccâriyye, Menâiyye, Sâbıkiyye, Hubbiyye, Havfiyye, Fikriyye, Hasbiyye, Münkiriyye ve Keseliyye veya Kesbiyye olup ${ }^{159}$ bunlardan Acziyye, Haşebiyye ve Münkiriyye daha önce zikredilmeyen fırkalar arasında yer alır. Acziyye, Efâliyye'ye benzer görüşlere sahiptir. ${ }^{160} \mathrm{Bu}$ üçü dışındaki diğer fırkalarla ilgili bilgiler daha önceki kaynaklarda zikredilenlerin bir tekrarıdır.

Beşinci olarak Müsebbibe'den bahsedilir. Bu fırkanın temel görüşü, Allah'ı yaratılanlara benzeterek, ona layık olmayan şeyleri nispet etmektir. Mezhebin görüşü ve ona verilen cevap faslından sonra Müsşebbihe, Mücessime, Hululiyye, Haddiyye, Târikiyye, Kavliyye, Valihiyye, Ameliyye, Sâibiyye, Sârikiy-

154 Krş, Nesefî, s. 88, 90; BG, vr.3a, 3-b; TM, s. 131.

155 Nesefî, s. 93; TM, s. 132; BG, vr.3b. 4-a.

156 Bkz." Zevidiyye", Nesefî, s. 92 ve TM, s. 124; "Ravendiyye", BG, vr. 3b. Aslında bunların hepsinin Ravendiyye fırkasını ifade ettiği açıktır. Bununla birlikte FM'de bu fırkaya nispet dilen görüş temelde diğerlerinkinden farklıdır.

157 FM, s. 58.

158 FM, s. 61

159 FM, s. 73

160 Acziyye'nin görüşü, "insanın bir yönden fiillerinde kesb sahibi olduğu ancak, bu fiili yapmama, ondan kaçınma imkânı olmadığı, buna mecbur olduğu” yönündedir (s.63). Neccâriyye'ye gelince, ona göre cisim, bir araya gelmiş arazlardan oluşur. Bu itibarla Kuran yazıldığında cisim, okunduğunda da araz olur. Ayrıca onlar müminlerin çocuklarının cennete, kâfirlerin çocuklarının ise ateşe gireceğin, öne sürerler (s. 66). Bu sözler daha öne hiçbir fırkada rastlanılmayan görüşleri ifade eder. Her ne kadar Münkiriyye fırkası daha önce $B G$ 'de zikredilmişse de, buradaki fırka ile aralarında benzer bir yön bulunmamaktadır. Burada Münkiriyye, Allah'la beraber başkalarının zikredilmesini hoş görmezken, $B G$ 'de aynı isimle zikredilen fırka şefaati reddetmektedir, FM, s. 72; BG, vr.8a. 
ye, Behşemiyye, Haşeviyye ve Kerramiyye olmak üzere on iki alt fırka zikredilir. Burada Müşebbihe'ye nispet edilerek zikredilen Târikiyye, Ameliyye, Sâibiyye, Sârikiyye Beheşmiyye ve Haşeviyye gibi fırkalar daha önceki eserlerde Mürcie fırkasının alt kolları olarak zikredilenlerdir.

Târikiyye ve Şâkkiyye fırkaları tek bir fırka şeklinde zikredilerek kendilerine aynı görüşler nispet edilir. ${ }^{161}$ Burada bunlara nispet edilen fikirler daha önceki eserlerde aynı isim altında geçenlerden farklıdır. ${ }^{162} \mathrm{Bu}$ iki fırkaya nispet edilen fikirler Nesefı ve BG'de Mürcie'in bir alt kolu olan Râciyye firkasına nispet edilen fikirlere benzemektedir. ${ }^{163}$ FM'e Kavliyye olarak geçen firka TM'de Sâibiyye olarak geçen fırkadır. Ayrıca bu fırkanın bir diğer ismi olarak Mücerride ismi zikredilir. ${ }^{164}$ Vahiliyye ismi altında zikredilen fırkaya, diğer eserlerde hem ismen hem de görüş olarak tesadüf edilmez. ${ }^{165}$

Sibiyye fırkası Nesefi'de aynı isim altında zikredilen fırka ile, $B G$ 'de $S e b b$ âbiyye şeklinde zikredilen fırkaya benzemektedir. ${ }^{166}$ Sârikiyye fırkası $B G$ dişında daha önceki eserlerde zikredilmemiştir. ${ }^{167}$ Behşemiyye, Nesefî, $B G$ ve TM'de Beyhesiyye olarak geçer. ${ }^{168}$ Haşeviyye olarak zikredilen firka önceki eserlerde zikredilmişse de, burada kendisine nispet edilen görüş çok daha farkl1dır.169 Haddiye olarak zikredilen firka diğer eserlerde ismen geçmese de, anlam olarak değişik isimler altında Cehmiyye'nin bir alt kolu olarak zikredilir. ${ }^{170}$

Altıncı olarak Muattıla fırkası ele alınır. Bu fırka için aynı zamanda Cehmiyye ve Zenâdıka ve Karâmita tabirleri de kullanılır. Bu firkanın temel görüşü, Allah hakkında menfi veya müspet hiç bir nitelemede bulunulamayacağı iddi-

161 Bu fırkalara göre taatleri yerine getirene itaatkâr, günah işleyene de isyankâr denemez. Çünkü itaatlerin küfür üzere, isyankârın ise, tövbe ederek, itaat üzere ölmesi ihtimali vardır. Böylece bir kimseye yaptıklarından dolayı mümin veya kâfir denemez (s. 78).

162 Nesefî ve TM'de Târikiyye'ye nispet edilen görüş, Allah'ın imandan başka kullarına herhangi bir şeyi farz kılmadığıdır (Nesefî, s. 114; TM, s. 135). Şâkkiyye hakkında Nesefî önce onların imam söz ve amel olarak kabul ederek, bütün amellerin imandan olduğunu öne sürdüklerini belirtir. Daha sonra da onların amelleri dışlayarak farz olarak sadece imanı kabul ettiklerini söyleyerek çelişkili bir ifade kullanır. Buradaki son ifadeleri Târikiyye için kullanılan ile aynıdır (s. 116). Böylece Nesefî'de de Târikiyye ve Şâkkiyye, FM’deki gibi, aynı görüşleri savunmaktadır.

163 Nesefî, s. $116 ;$; $B$, vr.8b.

164 Bu üç fırkaya nispet edilen görüş “İmanın Allah’tan başka ilah yoktur.” sözünden ibaret oldugudur, bkz. FM, s. 79; TM, s. 135 .

165 Bu firkaya göre "Allah hakkıyla bilinemez.", s. 81.

166 FM, s. 81; Nesefí, s. 115 ; BG, vr.8a.

167 FM, 82; BG, vr.8b.

168 FM, s. 83; Nesefî, s. 117; BG, vr.8b; TM, s. 135.

169 Burada Haşeviyye'ye nispet edilen görüş "kıyası reddetmeleridir.” s. 84.

170 Bu fırkanın temel görüşü “Allah’ın bir haddi olduğu ve onun mahdud olmadı̆̆ıdır.” Bu görüşe benzer şeyleri BG'de Cehmiyye'den Merfiyye fırkası savunurken (BG, vr.7a), FM, 'de Haddiyye'ye nispet edilir (s. 77). MM'de Müterâkibe olarak geçen Cehmî fırka nispeten benzer bir görüş ileri sürmektedir, s. 18. Nesefíde Mültezıkiyye adında tamamen zıt görüşleri öne süren bir firkadan bahsedilir, s. 106. 
asıdır. ${ }^{171}$ Ehl-i Sünnet'in ona cevabından sonra yazar on iki alt fırkayı zikreder. Bunlar Cehmiyye, Mahlûkiyye, Lafziyye, Merîsiyye, Vâridiyye, Kabriyye, Vezniyye, Meyliyye, Harkiyye, Fâniyye ve Zenâdıka'dır. Bunlardan Mahlûkiyye, Vâkıfiyye, Vâridiyye, Harkiyye, Fâniyye ve Gayriyye diğer eserlerde geçenlerle benzer özelliklere sahiptirler. ${ }^{172}$ Lafziyye firkası Nesefi'deki ile benzer görüşlere sahip iken, $T M$ ile zıt görüşleri savunmaktadır. ${ }^{173}$ Zenâdıka fırkası Nesefí'deki benzer ifadelerle zikredilir. ${ }^{174}$ Ayrıca FM'de bu firkaya nispet edilen bir diğer görüş de dikkate alınırsa, bu fırkanın Nesefı ve TM'deki Gayriyye, $B G$ 'deki Lağviyye firkası olduğu söylenebilir. ${ }^{175}$

Eserin son kısmında İslam dışındaki dinlerden "Kâfirlerin ve alt Sinıflartnın Zikredilmesi" başlı̆̆ 1 altında bahseder. ${ }^{176}$ Yazar bunları yirmi gruba ayırır. Burada yirminci sırada zikrettiği Melâhide ve Bâtıniyye firkasına özel bir önem atfedilir. Bu bölümde geçen diğer on dokuz alt grubun her birine bir iki cümlelik yer ayrılırken, Batıniyye'den ayrıntılı bir şekilde bahsedilir. ${ }^{177}$ Yazarın Bâtıniyye üzerinde genişçe durması, muhtemelen yazarın yaşadığ 1 dönemin siyasi, dini durumu ile alakalı olmalıdır. Nitekim Bâtıniyye'nin ele alındığı bölümün başındaki ifadelerden, ${ }^{178}$ eserin kaleme alındığ 1 dönemde Bâtınî hareketin son derece yaygınlaştığı ve toplumsal hayatı ciddi anlamda etkilediği anlaşılmaktadır. Bu anlamda Nizari İsmaililiğinin VI/XII. asırda bilhassa Selçuklularla ciddi bir mücadele içerisinde olduğu, faaliyetlerini siyasi ve toplumsal anlamda geniş bir alana yaydığı dikkate alınırsa, ${ }^{179}$ bu hususun öne çıkarılma gerekçesi daha anlaşılır bir hâl alacaktır.

Neticede bu eser daha önce zikredilen Nesefî, $B G$ ve $T M$ ye göre daha ayrıntılı ve daha sistematik bir yapı arz etmektedir. İlk üç eser fırkalara ait görüşleri çok kısa, bölük pörçük ve genelde anonim olarak vermeyi tercih

$171 F M$, s. 86.

172 FM, s. 88, 89, 90, 92-94.

173 FM ve Nesefî'de bu fırka Kuran'ın kendisi ile okunuşunun, yani lafız ve melfûzunun mahlûk olmadığını savunur. FM, s. 89; Nesefî, s. 113. TM ve $M M$ 'de Kuran'ın mahlûk olduğu yönünde tamamen zit bir görüşü savunur (TM, s. 134; $M M$, s. 18).

174 Her iki eserde de bu firka Allah'ın ve sıfatlarının idrak edilemeyeceğini öne sürmektedir (FM, s. 95; Nesefî, s. 108).

175 Zenâdıka, Gayriyye ve Lağviyye'ye nispet edilen bu görüş. Muhammed'in bilge bir kişi olup Kuran'ı eski filozofların sözlerinden meydana getirdiği görüşüdür. $F M$, s. 96; Nesefî, s. 111; $B G$, vr.7b; TM, s. 133 .

176 FM, 98-99.

177 FM, 100-114.

178 FM, s. 103.

179 Alamut sonrası Nizari-İsmailî faaliyetler hakkında geniş bilgi için bkz. Daftary Farhad, Muhalif İslam'ın 1400 yılı İsmaililer Tarih ve Kuram, çev. Ercüment Özkaya, Ankara 2001, s. 368-461; ayrica bkz. Hodgson, Marshal G. S., The Order of Assassins: the Struggle of the Early Nizari Ismailis against the Islamic World, The Hague 1955. 
ederken, bu eserde firkaların sahip olduğu görüşler daha ayrıntılı ve fırkalar belli şahıslara nispet edilerek verilmektedir. Ayrıca bu eserlerde daha önce ismi geçmeyen birtakım firkalar da zikredilmektedir.

\section{Ma'rifetu'l-Mezâhib}

Hanefî-Mâturîdî fırak geleneği altında incelemeye tabi tutulan bir diğer eser, Celaliyye Medresesinde Nazzam olarak bilinen müderris Mahmud Tahir Gazzalî (ö. 1044/1634) adında biri tarafından kaleme alınan Ma'rifetu'lMezâhib adlı eserdir. Eser aslında Farsça yazılmış olup, Ali Asğar Hikmet tarafından Arapça'ya çevrilerek neşredilmiştir. ${ }^{180}$ Eserin hemen başında yazar yetmiş üç firka hadisini rivayet ettikten sonra, bir başka hadise istinaden kurtuluşa erecek firkanın "Sevâdu'l-A'zam", yani Ehli's-Sünnet ve'l-Cemaat olduğunu belirterek kendi mezhebi kimliğine dair bilgi vermektedir.

Eser muhteva ve biçim yönünden Tezkiretu'l-Mezâhib adlı eserle çok büyük benzerlikler göstermektedir. Öyle ki aralarındaki farklılıklar birkaç cümle ile açıklanabilecek kadar azdır.

Yazar eserini yedi bölüme (bâb) ayırarak ele almıştır. İlk bölümde, Tezkiretu'l-Mezâhib'te olduğu gibi Abdullah b. Abbas'tan rivayet edilen Ehl-i Sünnet ve'l-Cemaat'in üzerinde birleştiği hususlar, yani Sünni olmanın şartları izah edilir. Ancak, TM'den farklı olarak, bu şartlar sekiz değil, on olarak zikredilmektedir. Sonra İman-İslam ilişkisi, muvahhid, mu'takid, mezhep, şerî‘at, mezhep sahibi, müçtehit, içtihat, millet, fırka, muslim gibi birtakım temel kavramlara dair izahatlarda bulunulur. ${ }^{181}$

İkinci bölümden itibaren, her bölüm bir ana fırkaya hasredilmek üzere, altı bölüm halinde fırkalar ele alınmaktadır. Ravâfız'a ayrılan ikinci bölümde TM'den farklı olarak, Eydiyye yerine Ebteriyye firkasından bahsedilmekteyse de, burada aynı fırkadan bahsedildiği yazarın ifadelerinden açıç̧a anlaşılmaktadır. Ayrıca Mütenâsihiyye yerine Tenâsühiyye tabiri kullanılmaktadır. ${ }^{182}$

Üçüncü bölümde Hâricî firkalardan bahsedilirken TM'deki ve Eciyye yerine Ahnesiyye fırkası zikredilir. ${ }^{183}$ İttifak ettikleri görüşler bahsinde, MM' de "Ali ve oğullarının Muaviye ve taraftarlarına karşı imamet mücadelelerinde haklı oldukları" belirtilirken, TM'de buna aykırı bir ifadeyle "Hakk'ın Muaviye'-

180 el-Fikru'1-'Arabiy, Sayı: 41 (1986), s. 9-22. Bundan sonra MM olarak zikredilecektir. 181 Ma'rifetu'l-Mezâhib, s. 11-13. Bundan sonra MM olarak zikredilecektir.

182 MM'de, TMYye göre, bazı fırkalar hakkındaki bilgilerin daha ayrıntılı verildiği dikkati çekmektedir. Mesela, İmamiyye fırkasında "Yeryüzü imamdan hali olmaz." cümlesi TM'de düşmüştür, yine Lainiyye firkasında $M M$ de Talha, Zübeyr ve Muaviye ile birlikte lanet edilenler arasında zikredilen Aişe TM'de geçmemektedir (MM, s. 14).

183 Ahnesiyye ve Eciyye firkaları da muhtemelen aynı firkayı ifade etmektedir, ancak MM'de "ölen kişinin ancak yaptığının karşılığını göreceği" ifadesi kullanılırken (s. 15, ), TM'de "ölen kişinin kıyamet gününe kadar iyi amellerden bir şey yapamayacağı belirtilmektedir.” (s. 128). 
nin elinde olduğu" belirtilir. ${ }^{184}$ TM'de Hariciliğin bir alt kolu olarak zikredilen ve görüsslerinden yeterince bahsedilen Mutezile, burada daha ayrıntılı olarak zikredilir. ${ }^{185}$

Dördüncü bölümde Cebrî fırkalardan bahsedilir. Daha önceki eserlerde Mafrûğiyye olarak zikredilen firka burada Mafrûdiyye olarak zikredilir. Ancak bu fırka Nesefî'deki Mafrûğiyye fırkası ile aynı görüşlere sahiptir. Bir diğer husus, daha önce Mutmainiyye olarak geçen firkanın MM’de Mütmeniyye tabirinin kullanılmasıdır. Ancak muhtemelen bu ikisi de aynı firkaya delalet etmektedir. ${ }^{186}$ Keza TM'deki Keselliyye olarak geçen fırka, MM'de Nesefí'deki gibi Kesbiyye olarak zikredilir. ${ }^{187}$ Son olarak, $M M$ 'de ismi geçen Habsiyye fırkası, TM'deki fırkayla görüş yönünden ortak bir yöne sahip değilken, Nesefî̀de geçen Hasbiyye firkasıyla aynı görüşleri öne sürmektedir. ${ }^{188}$

Beşinci bölümde, Kaderiyye'den bahsedilmektedir. Bu bölümde zikredilen bazı firkaların isimleri bazıları TM'den farkı olup aynı firkaya delalet ederken, bazıları da aynı isim altında zikredilmesine rağmen farklı fırkaları ifade etmektedir. Şöyle ki mesela, MM'de Ehadiyye olarak zikredilen fırka, TM'de Ahmediyye olarak geçer, ancak bunların aynı fırkayı ifade ettikleri açıkça ortadadır. ${ }^{189}$ Yine her iki eserde birbirinden tamamen farklı iki ayrı firkaya delalet eden bir Seneviyye fırkasından bahsedilir. ${ }^{190}$ Benzer bir durum Şerîkiyye fırkası için de geçerlidir. ${ }^{191}$ Butriyye-Müteberrie ve Nâsitiyye-Kâsitiyye tabirleri da aynı fırkaları ifade etmek için kullanılmış farklı isimlerdir. ${ }^{192} \mathrm{Bu}-$

184 Bkz. MM, s. 14; TM, s. 126

$185 \mathrm{MM}$, s. 15.

186 TM'de Mutmainiyye fırkasının görüşleri arasında yer alan "Nefsin beğenmediği şey kötüdür." İbaresi MM'de yoktur, bkz. TM, s.129; MM, s.16.

187 Fırkanın görüşleri ile ilgili ifadeler tamamen benzeşmese de aynı anlama ulaşmak mümkündür. Şöyle ki, Keseliyye fırkası, iyi veya kötü amel işlenmesinin sevap veya cezaya neden olmadığını söylerken, Kesbiyye sevap ve cezanın iyi veya kötü amel yoluyla artmayacağını ileri sürmektedir. Dolayısıyla her ikisinde de amellerin ceza veya mükâfata etkisinin olmadığı ortak görüşü mevcuttur (Bkz. TM, s. 129; MM, s. 16).

188 MM’de Nesefîye benzer biçimde, malların bölüştürülmemesi, ortak kullanılması meselesi dile getirilirken (s. 16), TM'de çok daha farklı bir durum olan. Tevrat'ı reddetmelerinden bahsedilmektedir (s. 130)

189 Bkz. MM, s. $17 ;$ TM, s. 131.

190 MM’de bu fırka “ İyiliğin Allah’tan, kötülüğün Rahman'dan olduğunu iddia eden bir firka iken (s. 17), TM'de âlemin iyiliği yaratan Yezdan ve kötülüğü yaratan Ehriman adında yaratıcısı olduğuna inanan bir fırkadan bahsedilmektedir (s. 131). MM’deki ilk cümle Nesefî ile aynıdır, ancak şerrin Rahman'a nispet edildiği ikinci cümle, sadece $M M$ de görülen bir husustur.

191 İki eserde bu firka hakkında söylenenler birbirine tamamen zıttır. MM'de bu fırkanın imanın yaratılmamış olduğu ifade edilirken. TM'de kulun işlediği ve Allah'ın yarattığı bir şey olduğu zikredilir. Burada yine MM'deki ifade Nesefî’ye daha yakındır. Nesefî'de iman dıșında bütün iyiliklerin takdir edilmiş ve yaratılmış olduğunu belirtilir. Böylece onda da imanın yaratılmamıș olduğu söylenmektedir. Bkz. MM, s. 17; TM, s. 131; Nesefî, s. 90.

192 TM, s. 132; MM, s. 17. 
rada dikkatimizi çeken bir nokta $M M$ 'nin $T M$ 'ye göre Nesefî̀ye daha çok benzerlikler gösterdiğidir.

Altıncı bölüm, Cehmî fırkalar hakkında olup TM'deki muhteva ve yapıyla uygunluk arz eder. Sadece Nesefî'de Mültezikiyye, TM'de Müterâfiyye olarak geçen fırka, MM'de Müterâkıbiyye; Râzıkiyye fırkasının da Zenâdıka olarak zikredilmesinin dışında herhangi bir farklı durum görülmez. ${ }^{193}$

Yedinci ve son bölüm, Mürcî̀ fırkalar hakkındadır. Burada aynı şekilde birtakım fırka isimlerinde farklılıklar olduğu gibi, aynı isim altında farklı görüş sahibi firkaların da zikredildiğini görmekteyiz. Öncelikle TM'deki Sâibiyye fırkası MM'de Şâniyye fırkası olarak; Beyhesiyye fırkası da Behşemiyye olarak geçmektedir. Râciyye fırkası TM'nin tersine Nesefî'deki ile aynı görüşü savunmaktadır. ${ }^{194}$ 'Ameliyye olarak zikredilen fırkanın görüşleri Nesefî ve TM'dekinden biraz farklıdır. TM'de bu fırkaya "İman organların amelidir." görüşü nispet edilirken, $M M$ 'de "İman, bilgiyle birlikte yapılan ameldir." görüşü kendisine nispet edilmektedir. ${ }^{195}$ Menkusiyye fırkası, TM'dekinden daha farklı, Nesefî'dekine benzeyen bir görüşü savunmaktadır. TM'de imanın artıp azalmadığı görüşü yer alırken, $M M$ 'de bu firka imanın Allah'ın lütfü ile artıp, gazabı ile azalacağım, bunda kulun bir payı olmadığını ileri sürmektedir. Yine Bidiyye fırkası $M M$ 'de "Yeryüzünde ortaya ç1kan her yeni meselenin Allah'ın iradesiyle ortaya çıktığını, dolayısıyla ortaya çıkan her yeni hükümdara, günah olanı emretse bile, itaat etmek gerektiğini" savunurken, TM'de aynı ismi taşıyan fırka "Allah'ın Âdem'i kendi suretinde yarattığı" görüşünü savunmaktadır. ${ }^{196}$ Nesefı bu noktada her iki eserden farklı bilgiler verir. ${ }^{197}$ Nesefî ve $M M$ 'de Müşebbihe firkası hakkında verilen bilgiler ile TM'de Bidiyye fırkası hakkında verilen bilgilerle karşılaştırıldığında, TM'de Müşebbihe'ye ait olan görüşün yanlışlıkla Bidiyye'ye nispet edildiği anlaşılmaktadır. ${ }^{198}$

Yedinci bölümden sonra eser tamamlanmış olmaktadır. Ancak yazar, eserin sonunda zikrettiği yetmiş iki fırkanın yanında ayrıca Ebû'l-Kâsım er-Râ-

193 MM, s. 18.

194 Daha önce zikredildiği gibi TM’de bu fırka, itaat veya isyan edenin itaatkâr veya isyankâr olarak isimlendirileceğini" öne sürerken, $M M^{\prime}$ 'de, Nesefî̀deki gibi, bu kişilerin itaatkâr veya isyankâr olarak isimlendirilemeyeceğini öne sürmektedir, MM, s. 18; TM, s. 135.

195 MM, s. 19; TM, s. 135.

196 MM, s. 19; TM, s. 136.

197 Nesefîdde Bidiyye fırkası "ümmette ilk olayları çıkaranların imamları inkâr edenler olduğu ve bu fiilerinin parçalanmaya sebep olduğu, dolayısıyla imama isyan edilmemesi gerektiğini” savunur. Burada her ne kadar $M M^{\prime}$ 'deki gibi yöneticiye itaat istense de, öne sürülen gerekçelerin farklı olduğu dikkati çekmektedir (Bkz. Nesefî, s. 123).

198 TM'de Bidiyye için Allah'ın Âdem'i kendi suretinde yarattığ ifadesi yer alır ki, $M M$ ve Nesefî'de bu ifade Müşebbihe için kullanılır. Doğrusunun bu olması gerekir (TM, s. 36; MM, s.19; Nesefî, s. 120 . 
zî’nin risalesinde Kerrâmiyye, Dehriyye, Habâbiliyye, ${ }^{199}$ İbâhiyye, Bâtıniyye, Berâhimiyye ve Eş'ariyye olmak üzere yedi firkadan daha bahsettiğini zikretmektedir. Burada TM'de belirtilen hususlar hemen hemen aynı ifadelerle tekrarlanır. Aynı şekilde TM'deki gibi, Eşariyye müstakil bir fırka olarak kabul edilmeyip Mutezile'nin bir alt kolu olarak gösterilmiştir.

Yine Ebu Hanîfe'nin el-Fıkhu'l-Ekber adlı eserinde geçen Mücessime firkasının varlığını haber verir. Eserin son paragrafında, yukarıda iki farklı yazardan nakledilerek zikredilen firkalar ve benzerlerinin tamamıla kendisinin zikrettiği yetmiş iki fırkanın alt kolları olduğu belirtilerek yetmiş iki sayısı korunur ve hadise muhalif kalınmamaya özen gösterilir. ${ }^{200}$

Neticede $M M$ 'de gerek muhteva gerekse biçim yönünden $T M$ ile büyük bir benzerlik göze çarpmaktadır. Ancak bu MM'nin TM'nin bir kopyası olduğu anlamına gelmez ve önemini azaltmaz. Çünkü birçok yerde $M M$, TM'deki bilgileri tamamlamakta, daha derli toplu bilgiler sunmaktadır. Ayrıca TM'nin Nesefî ile farklı olduğu noktalarda MM'nin benzer bilgiler verdiğini görmekteyiz. Bu bizi MM'nin TM'nin yanında başka kaynaklardan faydalanılarak yazıldığı sonucuna götürmektedir.

\section{Sonuç}

Genel anlamda ifade etmek gerekirse, Hanefî-Mâturîdî gelenek kapsamında kaleme alınmış eserler, diğer firak geleneklerinde olduğu gibi doğal olarak fırkaların tasnifinde 73 firka hadisine riayet etmede son derece hassas davranmışlardır. Hatta bu anlamda Hanefî-Mâturîdî fırak geleneğinin diğer fırak geleneklerine göre daha aşırıya kaçtığı dahi söylenebilir. Eserlerin gerek muhtevalarında, gerekse tasnifte esas alınan şablonun şekillenmesinde; fırkalara yaklaşım tarzlarında elimizdeki en eski metin olması anlamında Ebû Mutî‘ en-Nesefi'nin Kitâbu'r-Redd 'alâ Ehli'l-Bida've'l-Ehvâ' adlı eserinin belirleyici olduğu anlaşılmaktadır.

Bu geleneğin tarihi süreç içerisinde farklı fikrî ve tarihî merhalelerden geçerek geldiği dikkate alındığında, söz konusu geleneğin tek bir isim altında tanımlanması vakıayı ortaya koymada yetersiz kalmaktadır. Bu nedenle bilhassa İmam Mâtûrîdî öncesi döneme ait eserler için daha çok HanefíMürciî tabiri tercih ederken, Mâtûrîdî sonrası dönemi de ifade etmesi anlamında Hanefí-Mâtûrîdî nitelemesi kullandık. Dolayısıyla bu geleneği bir bütün olarak ifade etmesi anlamında Hanefî-Mâtûrîdî firak geleneği tabirini kullanmak yanlış olmaz. 
Dikkat edilmesi gereken bir diğer nokta, bu gelenekte, fırkalara ait görüşlerin son derece subjektif ve reddiyeci bir tarzda verilmiş olmasıdır. Fırkaların görüşleri, doğru ya da yanlış olmaları noktasında incelemeye konu teşkil etmiştir. Bu anlamda, asıl gayenin fırkaları benimsenen inançlar ve fikirler arasındaki benzerliklere göre bir araya toplayıp tasnif etmek; onları kendi mezhebi duruşlarına göre eleştiriye tabi tuttuktan sonra neticede $\mathrm{Hz}$. Peygamber ve ashabının yolu üzere inanan "firka-yı nâciye" olarak kendi haklılıklarını ispatlamak olması, fırkaların İslam düşüncesinin inkişafına herhangi bir katkıları olup olmadığı hususu tamamen göz ardı edilmesine yol açmışıtır. Dolayısıyla bu eserlerde, fırkaların isimlendirilmesi yanında, onların tasniflerinde ve birbiriyle ilişkilendirilmelerinde pek çok konuda çelişkili, yalan yanlış bilgiye yer vermeleri şaşırtıcı olmamalıdır.

Daha özele inildiğinde, söz konusu eserlerde farklı isimler altında zikredilen fakat aynı görüşü savunan iki fırkanın tek bir fırka olduğunu söylemek aksi ispatlanmadığı müddetçe savunulabilir. Özellikle fırkaların isimlerinde istinsah hatasından kaynaklanan bir farklılaşma olduğu ihtimali yüksekse, bu durum daha da geçerlilik kazanır. Nitekim geçmişte eserlerin kaleme alınma şartları, yazan kişiden kaynaklanabilecek hatalar vs. dikkate alındığında, bu durum daha da pekişmektedir. Buna ilaveten bu isim farklılaşması bir müstensihin yazım hatasından kaynaklanabileceği gibi değişik coğrafyalarda tek bir fırkanın iki farklı isim altında tanınıyor olma ihtimali olmadığını da göstermez. Dahası aynı isim altında zikredilen ve fakat kendilerine farklı görüşlerin nispet edildiği firkalar, aynı konuda birbirine tamamen zıt görüşler öne sürmedikleri müddetçe, bunların aynı fırkayı ifade ettiği; ancak onun değişik meselelerdeki görüşlerini zikretmiş olabilecekleri de unutulmamalıdır. 